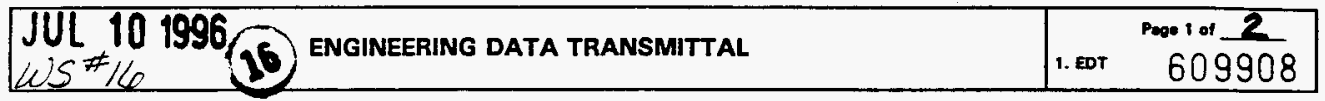

\begin{tabular}{|l|l|}
\hline $\begin{array}{l}\text { 2. To: (Receiving Organization) } \\
\text { Distribution }\end{array}$ & $\begin{array}{l}\text { 3. Fron: (Originating Organization) } \\
\text { PFP Process Engineering/15530 }\end{array}$ \\
\hline $\begin{array}{l}\text { 5. Proj./Prog./Dept./Div.: } \\
\text { PFP }\end{array}$ & $\begin{array}{l}\text { 6. Cog. Engr.: } \\
\text { E. P. Bonadie }\end{array}$ \\
\hline
\end{tabular}

8. Originator Remarks:

This is a technical report on the data, gathered to date, under WHC-SD-CP-TP-086, Rev. 1, on the integrity of the foodpack cans currently being used to store plutonium or plutonium compounds at the Plutonium Finishing Plant. A matrix found in the "Plutonium Inventory Characterization Implementation Plan" was used to categorize different plutonium items based upon the type of material being stored and the life expectancy of the containers.

11. Receiver Remarks:

* Do to database error document number had to be changed. Original EDT-609907 with signatures has been attached as sheet 2 of this EDT.

4. Related EDT No.:

609907

7. Purchase order No.:

$\mathrm{N} / \mathrm{A}$

9. Equip./Component No.:

$\mathrm{N} / \mathrm{A}$

10. System/Bldg./Facility:

$74 / 2736-Z / 2 Z$

12. Major Assm. Dwg. No.: $N / A$

13. Permit/Permit Application No.: $N / A$

14. Required Response Date:

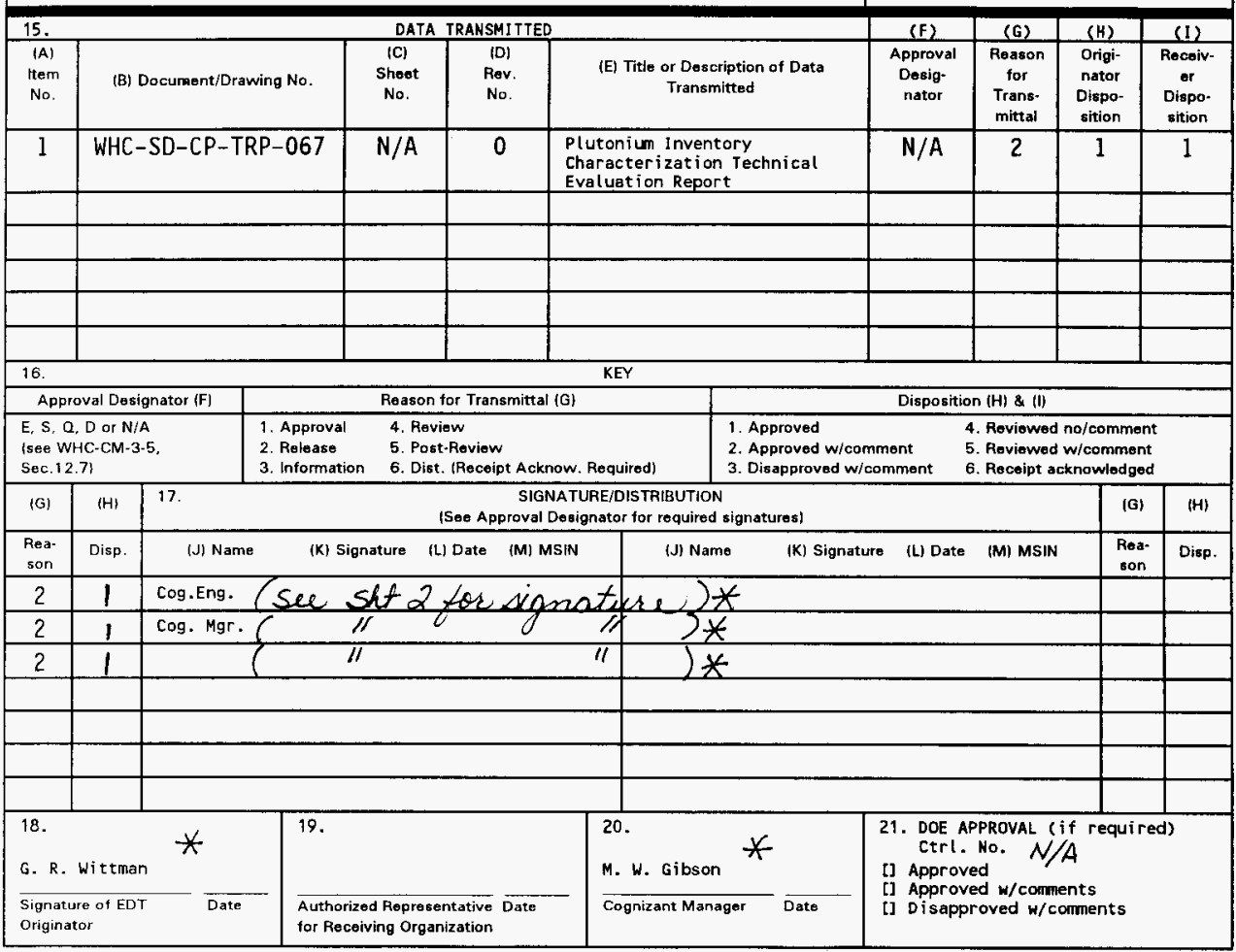




\begin{tabular}{|l|l|}
$\begin{array}{l}\text { 2. To: (Receiving organization) } \\
\text { Distribution }\end{array}$ & 3. From: coriginating Organization) \\
PFP Process Engineering/15530 \\
\hline $\begin{array}{l}\text { 5. Proj-/Prog-/Dept./Div.: } \\
\text { PFP }\end{array}$ & 6. Cog. Engr.: \\
\hline
\end{tabular}

8. Originator Remarks:

This is a technical report on the data, gathered to date, under WHC-SD-CP-TP-086, Rev. 1, on the integrity of the foodpack cans currently being used to store plutonjum or plutonium compounds at the Plutonium Finishing Plant. A matrix found in the "Plutonium Inventory Characterization Implementation Plan" was used to categorize different plutonium items based upon the type of material being stored and the life expectancy of the containers.

11. Receiver Renarks:
4. Related EDT NO.:

N/A

7. Purchase Order No.:

N/A

9. Equip./Component No.: $N / A$

10. Systen/Bldg./Facility:

$$
74 / 2736-Z / 2 Z
$$

12. Major Assm. Dwg. No.: $N / A$

13. Permit/Permit Application No.: $N / A$

14. Required Response Date:

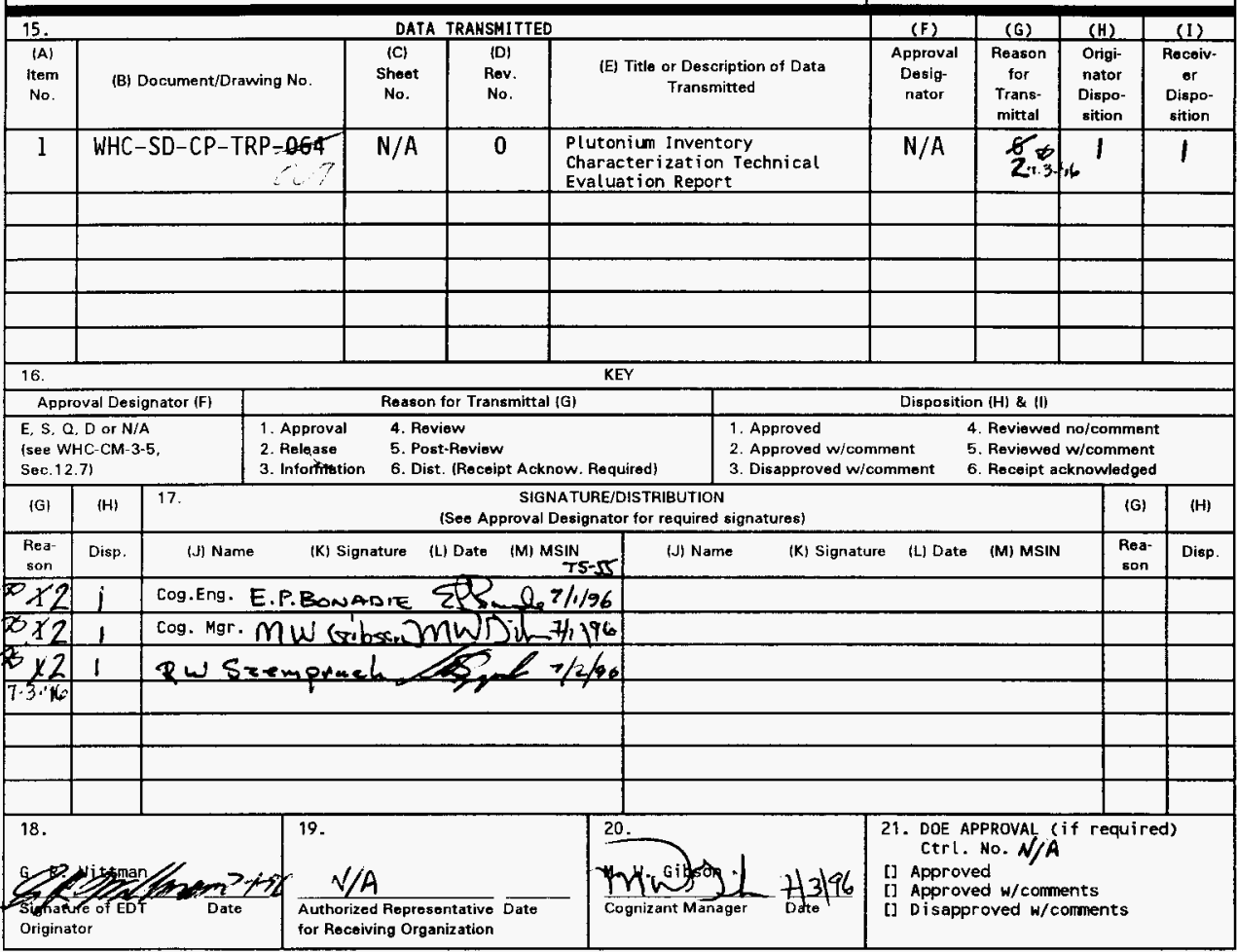




\title{
Plutonium Inventory Characterization Technical Evaluation Report
}

\author{
Gerald R. Wittman, Errol P. Bonadie, Richard W. Szempruch \\ Westinghouse Hanford Company, Richland, WA 99352 \\ U.S. Department of Energy Contract DE-AC06-87RL10930
}

$\begin{array}{llll}\text { EDT } / \text { ECN: } & 609908 & \text { UC: } 500 & \\ \text { Org Code: } & 15530 & \text { Charge Code: } & \text { K6145 } \\ \text { B\&R Code: } & \text { EW7003000 } & \text { Total Pages: } & 4647\end{array}$

Key Words: SNM Storage Containers; Foodpack Cans; Characterization; 2736-Z; Plutonium Storage

Abstract: This is a technical report on the data, gathered to date, under WHC-SD-CP-TP-086, Rev. 1, on the integrity of the foodpack cans currently being used to store plutonium or plutonium compounds at the Plutonium Finishing Plant. Workplan PFP-96-V0-009, "Inspection of Special Nuclear Material Using X-ray", was used to gather data on material and containment conditions using real time radiography. Some of those images are included herein. A matrix found in the "plutonium Inventory Characterization Implementation Plan" was used to categorize different plutonium items based upon the type of material being stored and the life expectancy of the containers.

TRADEMARK DISCLAIMER. Reference herein to any specific comercial product, process, or service by trade name, tradenark, manufacturer, or otherwise, does not necessarily constitute or imply its endorsement, recommendation, or favoring by the United States Governfent or any agency thereof or its contractors or subcontractors.

Printed in the United States of America. To obtain copies of this document, contact: WHC/BCS Document Control Services, P.0. BOx 1970, Mailstop H6-08, Richland WA 99352; Phone (509) 372-2420; Fax (509) 376-4989.
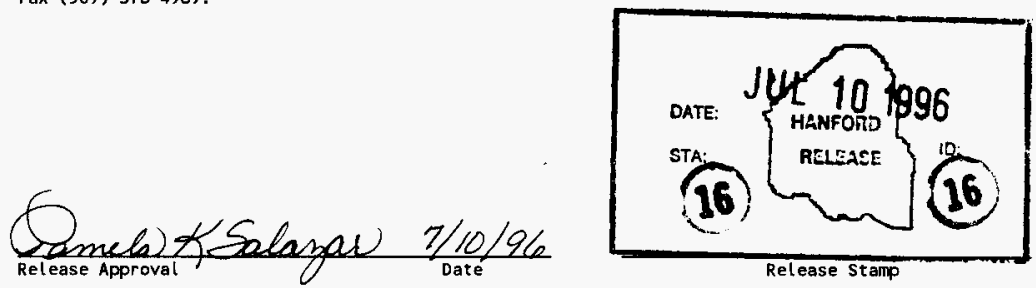

\section{Approved for Public Release}




\section{Plutonium Inventory Characterization Technical Evaluation Report

\author{
WHC-SD-CP-TRP-067 \\ REV. 0
}

June 1996 


\section{TABLE OF CONTENTS}

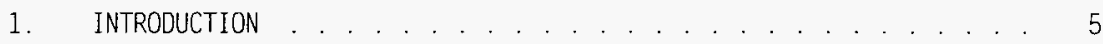

2. TEST METHOD AND TEST EQUIPMENT ................. . . . . 6

2.1 Destructive Test Methods . . . . . . . . . . . . . 6

2.2 Non-Destructive Test Methods . . . . . . . . . . . . . . . . 7

3. CORROSIVE OR REACTIVE "DRY" SOLIDS . . . . . . . . . . . . . . . 8

3.1 Description of Material Tested ............... . 8

Unstabilized Ash . . . . . . . . . . . . . . . . . . . . . . . . . . . . . 8

Slag and Crucible . . . . . . . . . . . . . . . . . . . . 8

3.2 Test Results . . . . . . . . . . . . . . . . . . . . . . 8

Unstabilized Ash . . . . . . . . . . . . . . . . . . . . . . 8

Slaq \& Crucible . . . . . . . . . . . . . 9

3.3 Conclusions and Recommendations ............ . 10

Unstabilized Ash . . . . . . . . . . . . . . . 10

\$lag \& Crucible . . . . . . . . . . . . . . . . . 11

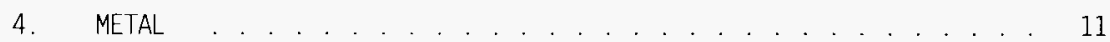

4.1 Description of Material Tested ............ 11

Buttons ................... . . . 11

Sma11 Metal Pieces . . . . . . . . . . . . . . . 12

4.2 Test Results . . . . . . . . . . . . . . . . . 12

Buttons . . . . . . . . . . . . . . . 12

Sma11 Metal Pieces . . . . . . . . . . . . . . . . . . . . . 17

4.3 Conclusions and Recommendations ................ 21

Buttons . . . . . . . . . . . . . . . . . 21

Small Metal Pieces . . . . . . . . . . . . . . . . . . 24 
WHC-SD-CP-TRP-067, Rev. 0

5. ALLOY . . . . . . . . . . . . . . . 28

5.1 Description of Material Tested . . . . . . . . . . . 28

5.2 Test Results . . . . . . . . . . . . . . . . . 28

5.3 Conclusions and Recommendations ............. 30

6. OXIDES AND COMPOUNDS (Not Product or Stabilized) . . . . . . . . 31

6.1 Description of Material Tested . . . . . . . . . . . . 31

Oxides ......................... 31

Laboratory Scrap . . . . . . . . . . . . . . . . . . . . . . 31

Plutonium Fluoride Source . . . . . . . . . . . . . . . . . . 31

6.2 Test Results ......................... 31

Dxides . . . . . . . . . . . . . . . . . . . 31

Laboratory Scrap . . . . . . . . . . . . . . . . . . . . 32

Plutonium Fluoride Source . . . . . . . . . . . . . . . . 35

6.3 Conclusions and Recommendations ............ 35

Dxides . . . . . . . . . . . . . . . . 35

Laboratory Scrap . . . . . . . . . . . . . . . 36

Plutonium fluoride Source . . . . . . . . . . . . . . . 36

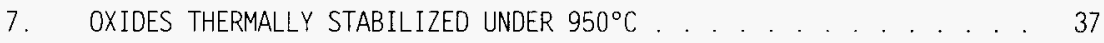

7.1 Description of Material Tested . . . . . . . . . . 37

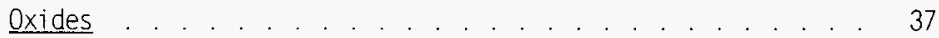

ARF-100-86-349 . . . . . . . . . . . . . . 37

Stabilized Ash . . . . . . . . . . . . 37

7.2 Test Results . . . . . . . . . . . . . . . . 38

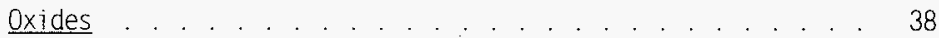

ARF-100-86-349 . . . . . . . . . . . . . . . 39 
WHC-SD-CP-TRP-067, Rev. 0

Stabilized Ash . . . . . . . . . . . . . . . . . 39

7.3 Conclusions and Recommendations ............ . . 39

Oxides . . . . . . . . . . . . . . . . . 39

ARF-100-86-349 . . . . . . . . . . . . . . . . . 39

Stabilized Ash . . . . . . . . . . . . . . . 40

8. OXIDES THERMALLY STABILIZED OVER $950^{\circ} \mathrm{C} \ldots \ldots 40$

8.1 Description of Material Tested ............ 40

Thermally Stabilized Material . . . . . . . . . . . . 40

8.2 Test Results . . . . . . . . . . . . . . . . 40

Thermally Stabilized Material . . . . . . . . . . . . 40

8.3 Conclusions and Recommendations . . . . . . . . . . 40

Thermally Stabilized Material . . . . . . . . . . 40

9. CONCLUSIONS AND RECOMMENDATIONS .............. 41

10. REFERENCES .................... . . . 43

11. APPENDIX $1 \ldots \ldots 44$

12. APPENDIX $2 \ldots \ldots . \ldots 46$ 
WHC-SD-CP-TRP-067, Rev. 0

\section{INTRODUCTION}

As part of the Westinghouse Hanford Company response to Recommendation 94-1 of the Defense Nuclear Facility Safety Board. a Plutonium Inventory Characterization Implementation Plan (Reference 1) was prepared. It laid out the framework to establish a safety basis for the prioritization of stabilization of materials based on systematic evaluation of data records. physical observations and empirica? container performance data.

The Implementation Plan presented a matrix. represented in Appendix 1 . that is an estimation of the relative risks of existing containers in inventory.

To carry out the details of the Implementation Plan. a test plan. WHC-SD-CP-TP-086, Rev. 1. "Plan to Examine Special Nuclear Material and the Foodpack Containers at the Plutonium Finishing Plant Storage vaults." (Reference 2) was written. This test plan described the technical basis and logic for the selection of containers to be examined. The items that were evaluated under this test plan were selected to represent the items of highest risk in their respective categories. 0lder packages, high radiation and high decay heat items were selected so that the condition of packages observed should represent the bounding worst case condition of inventory items.

The items examined can be broken into six different categories that are in the matrix:

1) Corrosive or reactive "dry" solids

2) Meta 1

3) A110y

4) Oxides and Compounds

5) Oxides therma $17 y$ stabilized under $950^{\circ} \mathrm{C}$

6) Oxides thermally stabilized over $950^{\circ} \mathrm{C}$

The materials selected are solid forms of plutonium stored in foodpack cans. Not included were plutonium solutions that are already considered as high priority to be processed into oxide. Polycubes. although in foodpack cans. also were not examined since their current storage configuration in vented containers classifies them as having low remaining container 7 ife. These polycubes are considered high priority and will be processed into oxide when process technology is developed. Mixed oxide fuel pins and assemblies were not examined because of the high integrity afforded by their cladding. 
WHC-SD-CP-TRP-067, Rev. 0

In March. 1996. 42 items were examined at the Plutonium Finishing Plant (PFP) using work plan PFP-96-V0-009, "Inspection of Special Nuclear Material Using X-ray" (Reference 3). Also, observations of container conditions were made between June, 1995 and Apri1, 1996. Observations were made and recorded while 127 containers were being opened for inventory verification sampling or stabilization processing.

Based upon the observed condition of the stored plutonium and the integrity of the foodpack cans, the relative container life expectancy on the matrix can be validated. If indicated. the containers can be assigned to a different category and priority for stabilization processing shifted accordingly.

This report documents the composite technical evaluation of all container observations and radiographs obtained between June. 1995 and Apri1. 1996 on 169 containers and their related data records. The impact of these data in the form of changes to the matrix and recommendations for future inventory characterization efforts are also presented.

\section{TEST METHOD AND TEST EQUIPMENT}

A total of 169 items were removed from vault storage and examined either destructively or nondestructively.

\subsection{Destructive Test Methods}

Destructive examination can be described as testing which results in changes to the properties of the plutonium containers and/or material characteristics. Plutonium stored in foodpack cans is retrieved from these containers by opening them with a can opener. Conditions such as corrosion, bulging. dents and penetrations were observed and recorded on the containers. The type and condition of the seal-out bag was also noted.

All containers, except ARF-100-86-349, the fluoride source (102-F-200-6) and a metal item, were opened due to required sampling or scheduled processing. The type of material that was opened for sampling was plutonium oxide. Stabilized and unstabilized ash was opened to be processed through the Thermal Stabilization Process.

Seven items in the form of plutonium oxide were opened in the repackaging glovebox located in 2736-ZB. Data on the condition of the cans was gathered while the items were being opened and sampled for other purposes. The material was repackaged and returned to the vault. One item (ARF-102-85-304) was videotaped while it was being opened.

Seventy items of stabilized ash and forty seven items of unstabilized ash were opened to be processed in the Thermal Stabilization Process. 
WHC-SD-CP-TRP-067, Rev. 0

Data on the condition of the cans was obtained as the items were opened The material was processed to over $950^{\circ} \mathrm{C}$ and the material was then packaged and returned to vault storage.

\subsection{Non-Destructive Test Methods}

Using WHC-SD-CP-TP-086. Rev 1, "Plan to Examine Special Nuclear Material and the Foodpack Can Storage Containers at the Plutonium Finishing Storage Vaults". work plan PFP-96-V0-009 was written to examine items by radiography. Items were selected using the appendix from

WHC-SD-CP-TP-086, Rev 1.

The goal of using radiography was to gather information, on the condition of the items selected, in a quick and efficient manner without exposing personnel to high doses of radiation.

The items were $X$-rayed using radiography equipment consisting of a control unit with image display. X-ray generating unit. $X$-ray imager. and electrical cables connecting the equipment together. The $X$-ray generating unit and imager were placed into the storage vault. A $90^{\circ}$ cable was laid from the material storage vault to corridor 625 in 2736-ZB where it was connected to the control unit.

As a safety feature. there are two interlock switches for the radiography equipment. One keyed interlock is located in the $X$-ray generating unit and the other, in the control unit. The Vault Operations (VO) operator and vault technician were not allowed entry into the storage vault unless the vo operator had possession of the control unit key. The $X$-ray image was acquired only after a 11 individuals left the storage vault and the control unit key was returned to the $X$-ray system operator.

To achieve image acquisition. the selected item was placed in front of the $X$-ray imager. An $X$-ray image was taken and visually inspected to determine whether additional views of the item were needed to assess internal container/material conditions. If required, the item was then partially rotated one or more times and additional images acquired.

The $X$-ray images were saved as digital graphic files and may be retrieved for viewing or printing. A number of those images are included in this document. All of the X-ray images with related data sheets may be found in the appendix to this document which is in WHC-SD-CP-TRP-065. Based upon the information gathered from the X-ray images, items will be selected for opening and closer examination. Reasons to select an item include questionable container integrity/packaging configuration as well as the need to verify conditions seen on the radiographs. 
WHC-SD-CP-TRP-067, Rev. 0

3. CORROSIVE OR REACTIVE "DRY" SOLIDS

\subsection{Description of Material Tested}

\section{Unstabilized Ash}

Cans of incinerator ash containing carbonaceous material were received and most were calcined at $600^{\circ} \mathrm{C}$. between 1984 and 1986 . Forty seven ash items remained unstabilized when the process was shut down. Due to concerns about this ash building pressure within the foodpack cans. these items were stored in a vault with specially designed drawers. These drawers have ventilation on them in case an item stored within them ever ruptures.

Since the life expectancy of the unstabilized ash items was expected to be relatively low. a 1147 items were considered high priority and processed through the Thermal Stabilization Process in 1995. The 47 unstabilized ash items were opened in glovebox $\mathrm{HC}-21 \mathrm{~A}$ where material was accounted for before it was processed. The foodpack cans were visually examined for degradation as they were opened. The plutonium content for each item ranged from 10 to 184 grams. Some samples were taken for Loss On Ignition (LOI). Some items were videotaped while they were opened. Data on the LOI may be found in Reference 5 . The list of items can be found in the appendix.

\section{Slag and Crucible}

Six Slag and Crucible lard can packages were examined by radiography. The plutonium content ranged from 42 to 322 grams. There are as many as ten untinned slag and crucible cans stored (up to a plutonium 7 imit of 400 grams) in each $501 \mathrm{~b}$ lard can. These untinned cans were packaged between October of 1985 and May of 1989. The untinned cans which contain the slag and crucible were not removed from the $50 \mathrm{lb}$ lard cans. Note: A $50 \mathrm{lb}$ lard can has a diameter of approximately 12" and a height of approximately 15".

\subsection{Test Results}

Unstabilized Ash

Detailed information was gathered on thirty of the forty-seven items representing $64 \%$ of unstabilized ash in the inventory. These items were visually inspected while being opened to be processed through the Thermal Stabilization Process. The material is usuaity a fine powder but. as witnessed, can contain chunks of material.

There were two different types of storage configurations for these items, each a collection of nested foodpack cans. 
The first configuration consisted of three foodpack cans. The material was contained by a one 1b slip-1id ( $\left.31 / 2^{\prime \prime} \times 31 / 2^{\prime \prime}\right)$ or a PUREX slip lid can (3 7/16" X 5 5/8"). Next was a poiyvinylchloride (PVC) seal-out bag to remove the material container from the glovebox. The PVC seal-out bag was often placed into a polyethylene (PE) bag. The PE bag was then horsetailed (ie. twisted on the open end and then taped). These were canned into a sma 11 tomato can $\left(41 / 16^{\prime \prime} \times 45 / 8^{\prime \prime}\right)$ or a PUREX secondary can (4 1/16" X $\left.61 / 4^{\prime \prime}\right)$ and overpacked in a seven inch can (4 1/4" $\times 7 "$ ).

The second storage configuration consisted of two foodpack cans. The material was packed into a PUREX secondary can within a glovebox. This was then sealed out of the glovebox in PVC and canned into a seven inch can. Thirteen of the 30 items had the crimp sealed PUREX secondary can as the material can. All but one item appeared to be sealed out in PVC. It should be noted that the type of plastic used to seal out the material cans was determined based solely on a visual inspection.

The exterior of the $7 "$ can of twenty nine of the thirty items showed no sign of any problems that would impact the integrity of the container. However. one of the thirty items. ARF-101-86-44, had bulged top and bottom end plates to the extent that the can could be rocked on a flat surface. There were two foodpack cans in this item's configuration. The inner material can was not observed as butged. There was evidence of pressure in the PVC seal out-bag, as it was expanded to the walls of the exterior container. It is assumed that the off gas from the material leaked out of the material can. When the material can was opened, the material puffed out of the can for approximately two seconds. The opening of this item was videotaped.

One item. ARF-101-86-51, had the material can inside a PVC seal out bag which was inside a PE bag. The PE bag was expanded fully due to off gassing from the material inside the material can. The PVC seal out bag did not contain pressurized off gas.

Another item. ARF-101-85-789, had a bulged inner material can. This item was also packaged in two foodpack cans. The PVC seal-out bag also had some discoloration on it but showed no signs of pressurizing. The material can was bulged on both ends. The two ends were bulged out approximately 1/2" and 3/4" but was still pressurized. To open the item. the operator had to pound one end down. further compressing the gas in the can. Material spewed out for approximately five seconds when the item was opened. The material can did have some rust on the exterior surface. The opening of this item was videotaped.

\section{Slag \& Crucible}

Six slag and crucible items were selected and examined by radiography. The $X$-ray images were difficult to evaluate due to several untinned cans being stored in a cluster within the $50 \mathrm{lb}$ lard can. One of the clearer 
radiographs is shown in Figure 1. The lard cans will have to be opened and each untinned can retrieved and examined in order to obtain more detailed information. There was no evidence of any deformed cans of slag and crucible.

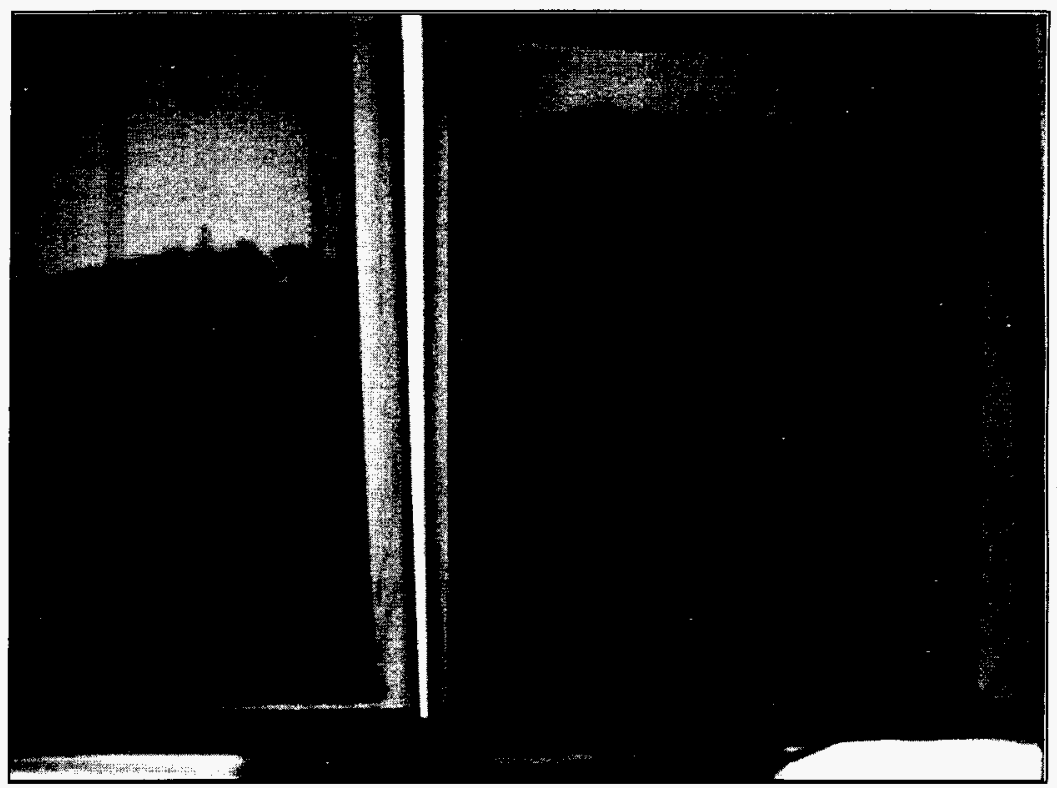

Figure 1 - Radiography image of untinned slag and crucible cans inside a 50 lb lard can. No visible sign of can corrosion is evident.

\subsection{Conclusions and Recommendations}

Unstabilized Ash

Several unstabilized ash items when opened. were found slightly pressurized. This was not totally unexpected due to the fact that it was recognized that these containers were not thermally stabilized on receipt to fully drive off volatiles. All of the unstabilized ash was processed through the Thermal Stabilization Furnaces at ca. $950^{\circ} \mathrm{C}$. Subsequent LOI testing resulted in $<0.5 \%$ volatiles. Since al of the unstabilized ash has now been processed, there is no need to address 
WHC-SD-CP-TRP-067. Rev. 0

this category further. A11 47 items have moved from the category of "Corrosive or Reactive "Dry" Solids" with Remaining Container Life Expectancy - Low-Medium, found in Table 2, to the "Oxide Stabilized $>950^{\circ} \mathrm{C}$ " with Remaining Container Life Expectancy - Medium-High found in Table 3

\section{Slag \& Crucible}

The untinned cans were not removed from the lard cans in which they are currently being stored. As a result. it is difficult to determine the condition of most of the slag and crucible items due to multiple layers of cans overlapping on most of the X-ray images. No detectable problems were discovered but data is not conclusive. A work plan to examine individual items outside of the lard can will be written and implemented.

4. METAL

\subsection{Description of Material Tested}

The plutonium metal inventory contains large (about 2 kilograms) pieces of plutonium commonly referred to as buttons and smal7er mass items that are on the order of a few hundred grams. Some of the metal has been in storage for over 25 years. Twenty items were examined using radiography and one item was opened for inspection.

\section{Buttons}

A total of sixteen buttons were examined using radiography. The metal items selected typically were fuels grade plutonium (about $16 \%{ }^{240} \mathrm{Pu}$ ) and over 25 years old. These were selected because they represented the high end of the decay heat and age spectrum of the metal category. Therma? decay heat of the buttons examined was in the 10 to 12 watt range. Records indicate that a 11 of the metal items that were examined were packaged at Hanford. The metal items were packaged in several different configurations because of the packaging practices in use at the time of packaging. Based on past practices and review of old operating procedures all metal items are expected to have been packaged in dry air gloveboxes. A tygon tube applied argon flush of material cans prior to applying the lid has been used in the past but it has not been determined when the practice was started. The metal generally was first packaged either in a material can or tightly wrapped in aluminum foil. It was then sealed in a plastic glovebox seal-out bag. Both polyvinylchloride and polyethylene have been used for glovebox "sealouts". The bagged out item typically will be packaged into one or more clean foodpack cans for vault storage. 
WHC-SD-CP-TRP-067, Rev. 0

\section{Sma11 Meta1 Pieces}

Four smal1 pieces of metal were examined by radiography and one was opened for inspection. The age of these items ranged from about ten years to over 25 years. The packaging configuration was expected to be similar to that of the buttons described above.

Two of the items. categorized as Laboratory Scrap, were chosen for inspection by radiography because records indicated that the net weight of the material nearly equaled the plutonium weight in the container suggesting the contents were metal. As an example, item 41-88-09-214. was chosen because the plutonium weight was recorded as 352 grams and the net weight was 355 grams indicating that this item was greater than 99\% plutonium. Another item categorized as Recastable Metal (Item No. 92-79-02-01), and a partial button were examined using radiography. Based on review of records, another portion of the partial button that was radiographed was located and taken to a glovebox and opened for inspection

\subsection{Test Results}

Buttons

Sixteen plutonium metal buttons were examined by radiography. Several different container configurations and condition of metal were observed. The container configurations may be generally described as either a four can system or a two can system.

The radiograph shown in Figure 2 depicts the four container system. The metal is stored in a small crimp sealed foodpack can. Based on knowledge of past practices, it is believed that this can was bagged out of the glovebox and placed in a tape sealed one pound slip lid ( 3.5 inch diameter by 3.5 inch $\operatorname{ta11}$ ) can. This could not be confirmed by observation on the radiographs. This slip lid can was then over packed in two clean crimp sealed cans. The inner of these sometimes referred to as a tomato can is typically 4-1/16 inches diameter by 4-5/8 inches tal1. In all cases the outer can was 4-1/4 inches diameter by 7 inches ta17. Can bodies used for these two outer containers were both straight wall and "indented rib" types. Twelve of the sixteen buttons examined were packaged in four cans as previously described.

The two container system observed in four instances is illustrated in Figure 3. The innermost material can is the same small crimp seal can and the outer can is the same 7-inch tall can as used in the four container system. 
WHC-SD-CP-TRP-067. Rev. 0

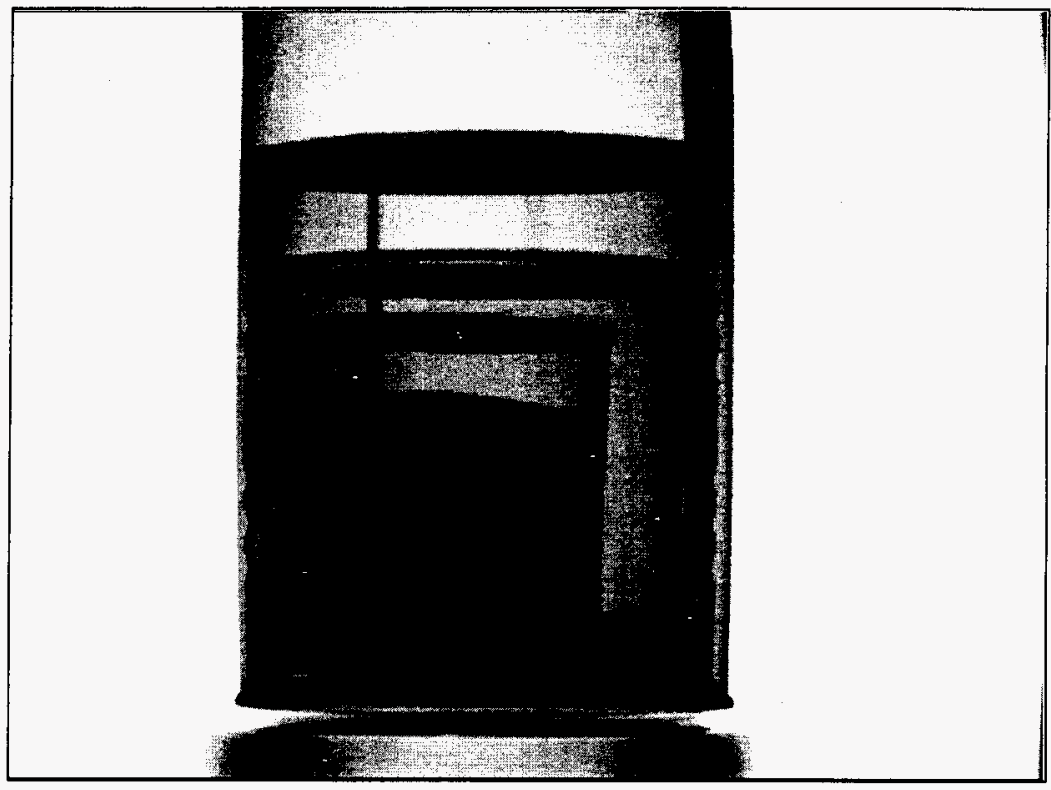

Figure 2 - Plutonium button stored in four cans. Note the slip lid can is upside down.

Three of the sixteen buttons examined had the innermost material can deformed inwardly as illustrated in Figure 4 . ATl of these were observed in the four container system configurations. Inward deformation of containers has been observed on several occasions. Separate instances that occurred at Hanford in 1974 and 1983 were reported in Reference 7 and Reference 8 , respectively. A simi lar condition was observed at Savannah River Plant and reported in Reference 9 and another is understood to have been observed at Lawrence Livermore National Laboratory in August 1995. A1l instances involved high decay heat plutonium, similar in plutonium isotopic distribution to those radiographed 
WHC-SD-CP-TRP-067. Rev. 0

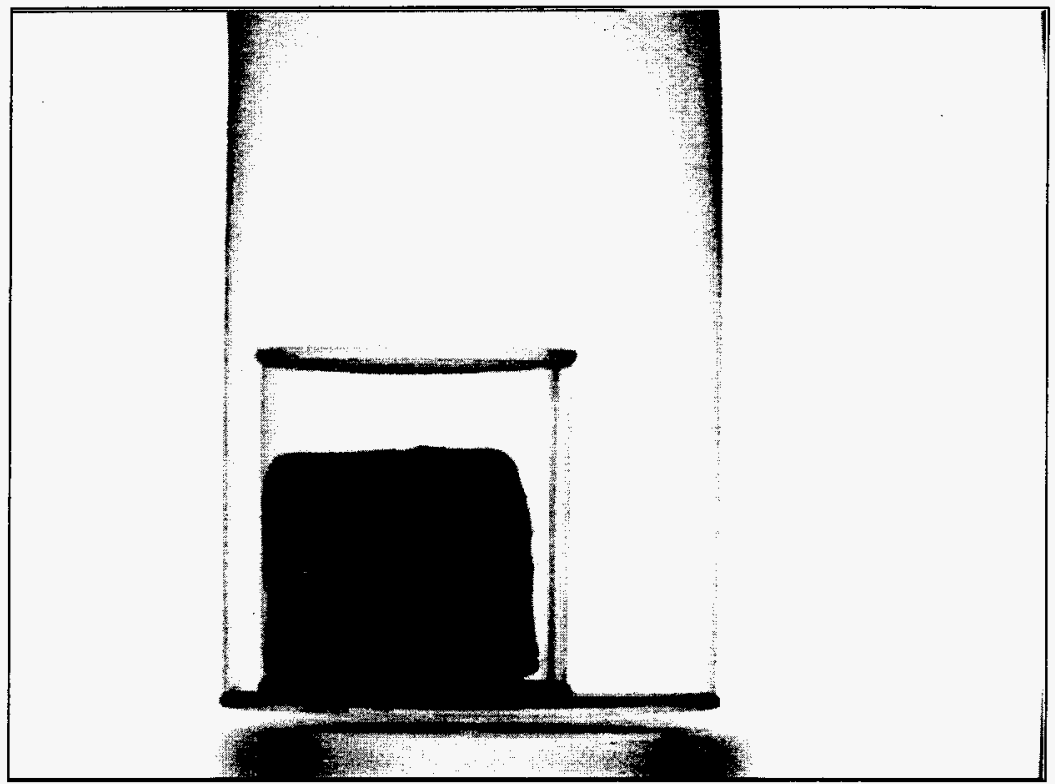

Figure 3 - Plutonium button stored in two foodpack cans

Of the twelve items with the four can configuration as shown in Figure 2 . four of the tomato cans showed evidence of slight pressurization while eight appeared to be under negative pressure. The positive pressure condition is i17ustrated in Figure 5 . This Figure also shows a deformed inner can. Of the three items with buckled inner cans, two had slightly pressurized tomato cans.

The extent of metal corrosion varied from little observable corrosion such as shown in Figure 3 to the worst shown in Figure 5. 


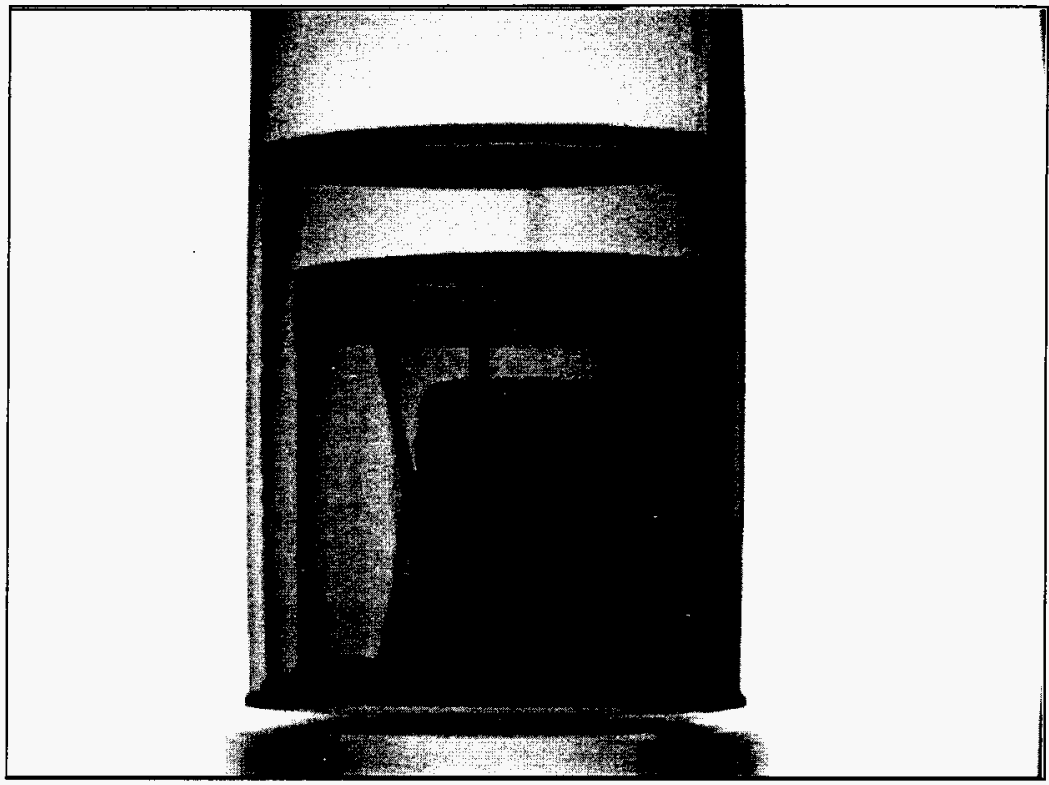

Figure 4 - Material can is deformed

As part of the data gathered during the radiography effort, the containers were weighed and compared to the gross weight recorded on the labels of the containers. The label weights were recorded to the nearest gram while the current weights were recorded to the nearest tenth of a gram. The inventory data base was reviewed to determine when labels were applied. These data indicate most were applied prior to the establishment of the data base around 1981 which is consistent with the age of the material. The range of differences in weight was minus 0.9 gram to plus 3.1 grams. Plant procedures call for button brushing to remove oxide and repackaging whenever an increase in can weight greater than five grams is observed. Such weight gains are indicative that containers are not hermetically sealed and the metal has undergone some degree of oxidation. Removal of the oxide and repackaging in new cans would result in a new gross weight for the item that would be recorded in the data base. For the 15 year period recorded in the data base none of the radiographed metal buttons had a record of weight change other than that associated with application of tamper indicating seals. 
WHC-SD-CP-TRP-067. Rev. 0

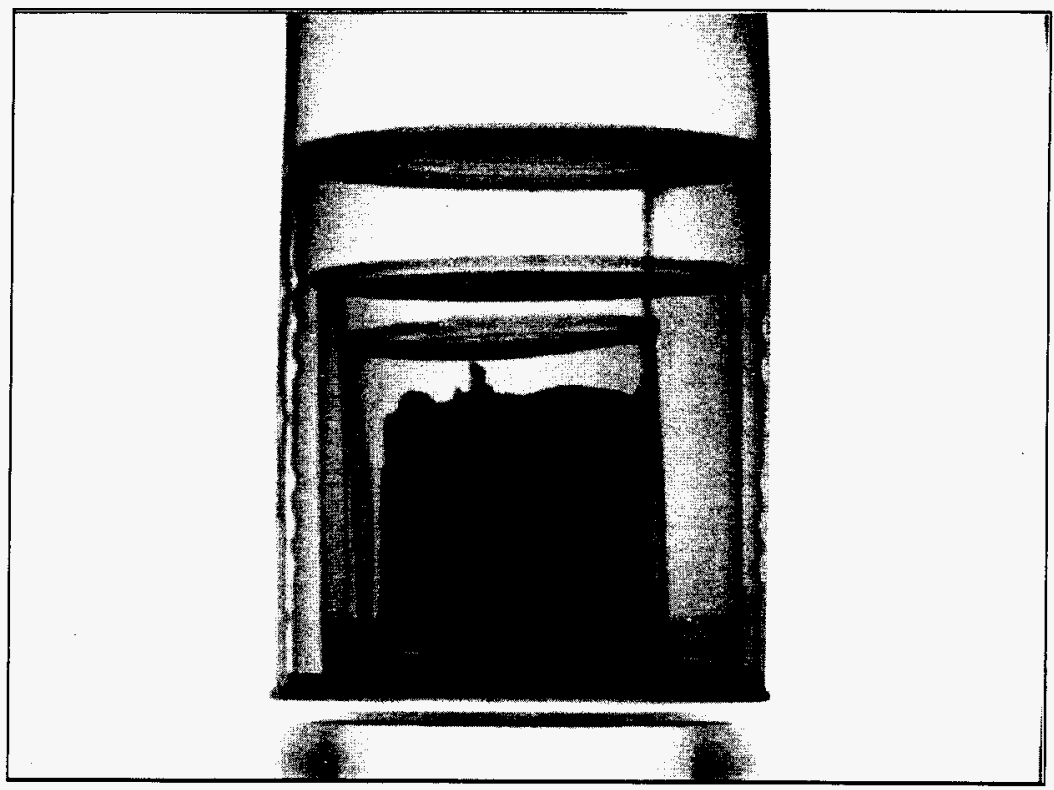

Figure 5 - Plutonium metal inside four cans. Material can deformation is visible on the left side while the tomato can, which is the third can from the inside, shows signs of being slightly pressurized. 
WHC-SD-CP-TRP-067. Rev. O

\section{Sma11 Metal Pieces}

+ Plutonium Metal Shavings (Item 41-88-09-214)

The X-ray images of 41-88-09-214 (see Figure 6) revealed plutonium metal shavings inside a 1-1b slip 7id can. The 1-1b slip lid can was then sealed out into a polyvinylchloride or polyethylene seal-out bag and then packaged into a tomato and 7 " can. The shavings do not appear to be significantly oxidized. This item did gain 1.5 grams since 1988.

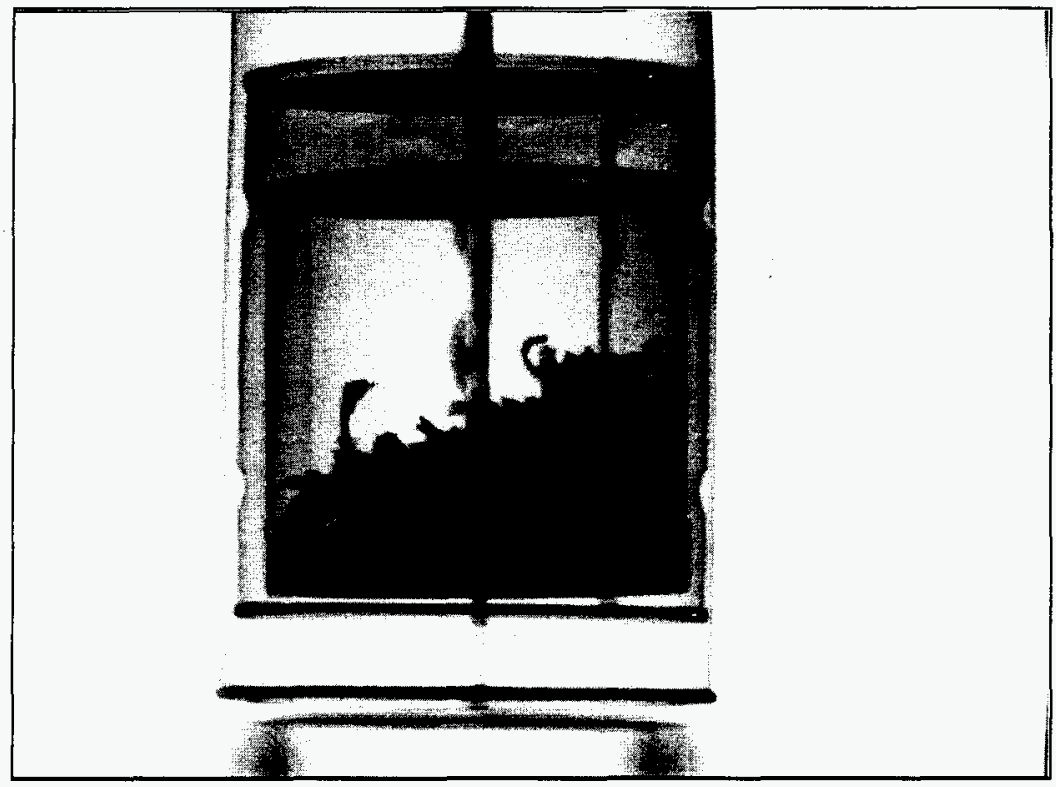

Figure 6 - Item 41-88-09-214

appears to be metal shavings. 
+ Metal Chunk (Item 41-84-11-446)

The X-ray image (see Figure 7) shows a small chunk of metal inside what appears to be a glass jar. This was sealed out and canned into a tomato can and overpacked in a $7^{\prime \prime}$ can. In 1984, the gross weight of the item was recorded to the nearest gram as 614 grams. In March of 1996 . the gross weight was 615.1 grams, a gain of 0.6 to 1.6 grams depending on how much 614 was rounded. Based on weight gain and the $x$-ray image, the metal does not appear to be significantly oxidized. Assuming that oxidation is occurring slowly. this item is expected to last another 10 to 50 years in its current configuration.

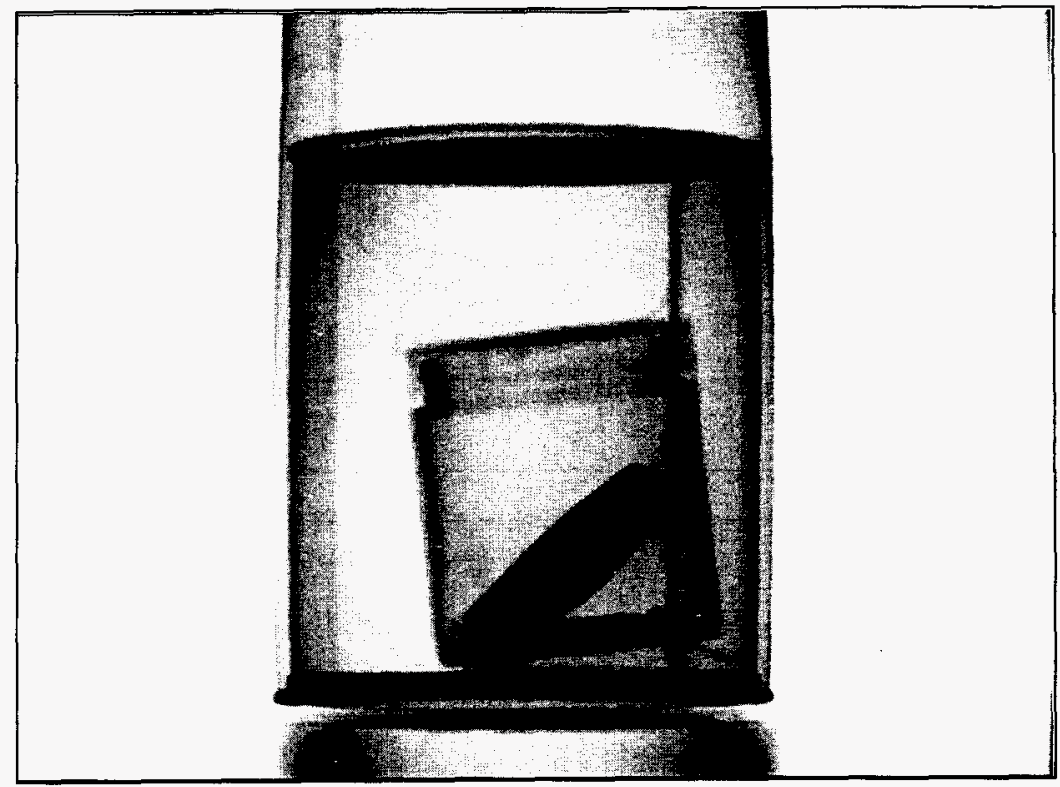

Figure 7 - Item 41-84-11-446 is a piece of plutonium metal. 
+ Recastable Metal (92-79-02-01)

$X$-ray images of 92-79-02-01 (see Figure 8) show what appears to be some loose powder with the metal item. The metal is packaged in a small slip lid can and overpacked with three crimp sealed cans. The label weight was the same as the balance weight. The foodpack can ends appear to be slightly deformed inwards.

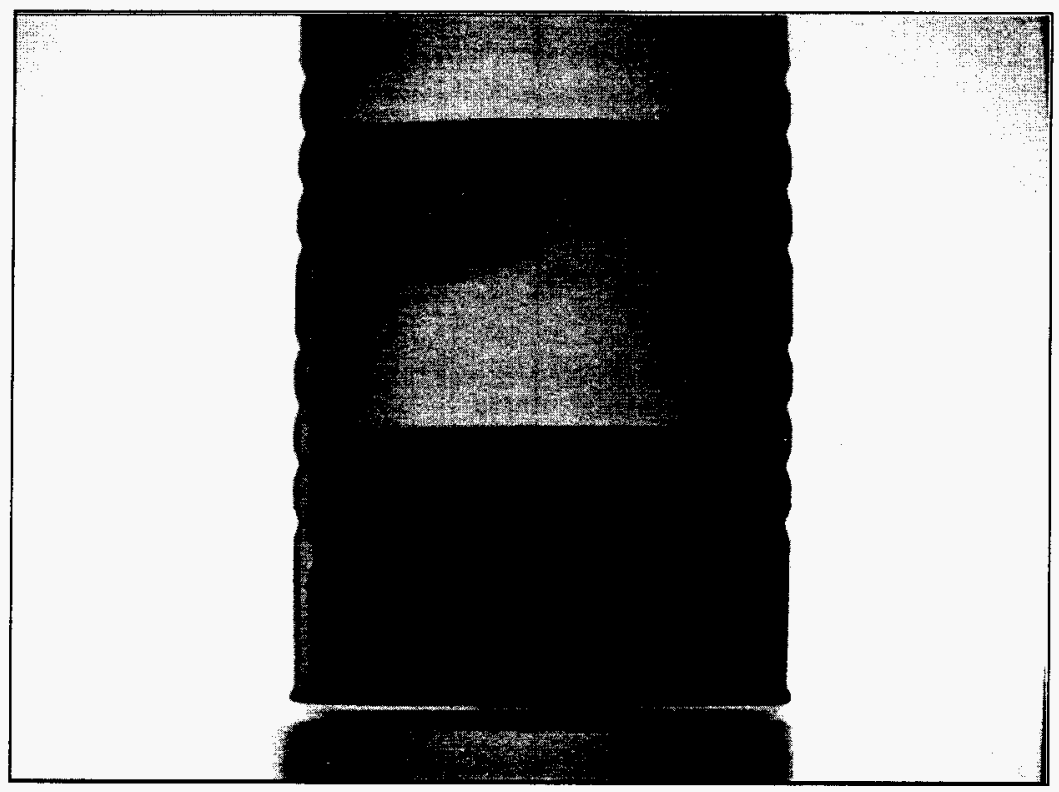

Figure 8 - Recastable metal with some indication of oxidization.

+ Partial Buttons

One partial button was examined using radiography. This partial button shown in Figure 9 appears as if it may have been bagged out of the glovebox directly in plastic. The gross weight of the container was 491.7 grams compared to 489 grams on the can label. The can contained 213 grams of plutonium meta 7 . 
WHC-SD-CP-TRP-067, Rev. O

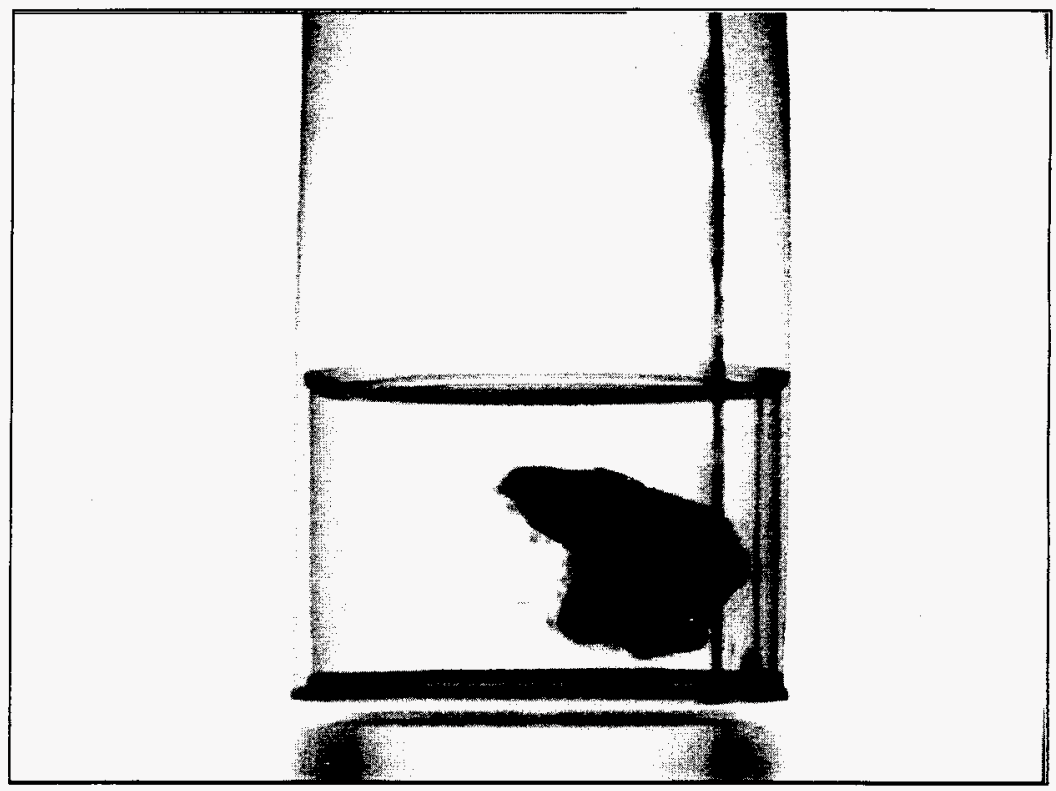

Figure 9 - Partial Metal Button

Based on the observations discussed above, another portion of the original button was opened for visual examination. It was observed that the metal had been wrapped in aluminum foil which was sealed out of the glovebox in PVC. canned in a pineapple can. and overpacked in a seven inch can. This item appears to have been packaged identically to that observed in Figure 9. After seventeen years of storage, the metal partially oxidized. 
WHC-SD-CP-TRP-067, Rev. 0

\subsection{Conclusions and Recommendations}

\section{Buttons}

The collected data were analyzed to determine whether there are any indications of past or imminent failures of the packaging that could pose a risk of contamination release to the storage vault. Although there are some indications of undesirable conditions, none of the observed containers showed signs of such past or imminent failures. The variations in container configurations, condition of metal and condition of containers appear at first confusing but are supported by historical facts, chemistry and physics.

These sixteen items came into existence in the late sixties and early seventies. Based on historical knowledge all the buttons were very likely originally packaged in the small crimp sealed can. followed by a seal-out bag. This was then packed into a slip-lid can which was then placed into vault storage. Reference 7 identified two significant vault contamination incidents that occurred just prior to 1970 involving similar material in which oxidation of the metal caused rupture of the slip lid can and release of oxide. In response to these incidents, technical evaluations of metal packaging performance, such as Reference 10. resulted in overpacking the containers with two food pack cans to exclude additional air from entering the material containers. This sequence of actions resulted in the four can configuration.

If during subsequent storage the container appeared to be bulged or gained weight in excess of 5 grams, that item would be moved into a glovebox, opened, the metal brushed, and repackaged. Prior to 1978 when the PFP established formal Operating Specifications focussed on safety of material stored in vaults, such a repackaging activity could have resulted in the two can configuration. Subsequent to that date. the Operating Specification required two contamination-free metal cans to be the outer two containment barriers. There was generally less corrosion of plutonium metal evident in the two can configuration as compared to the four can configuration. This is consistent with having brushed these buttons subsequent to original packaging.

Both positive and negative pressure conditions of the tomato cans are explainable. Reference 8 indicates that plutonium nitride can be formed by combination of nitrogen with elemental plutonium at elevated temperatures. If the innermost material can's atmosphere is air such a reaction is possible. This would create a vacuum in the material can capable of buckling the can. Even a slight leak of this can would allow in-leakage of air from inside the slip 7 id and tomato cans since the taped slip lid can is not expected to be an effective gas seal. This in-leakage in turn causes the tomato can to be under a vacuum because of the consumption of air by the corrosion of the plutonium metal. On the other hand, if the innermost material can does not leak, the gas in the slip 7 id and tomato cans would be air. Heating of this air would cause 
WHC-SD-CP-TRP-067, Rev. O

a slight pressurization of the tomato can. Calculated pressures for estimated storage temperatures results in pressures on the order of 5 psig. The extent of can end plate deformation observed is consistent with pressures in this range. Both conditions indicate good container seals on the tomato cans.

The greatest weight gain was 3.1 grams. If it is assumed that this is from inward migration of air and corrosion of the plutonium metal an estimate of this leak rate can be made. Using the Ideal Gas Law and the molecular weight of nitrogen, 3.1 grams would occupy a volume of 2.5 liters at standard conditions ( 3.1 grams/28 grams per gram mole $\times 22.4$ liters per gram mole). If one assumes a fifteen year period (back to the age of the data base rather than the original packaging date) as the basis for duration of leakage the rate can be calculated. There are 4.7 $\times 10^{8}$ seconds in the leakage period. The calculated leak rate is $5 \times$ $10^{-6} \mathrm{cc} / \mathrm{sec}$. This value is consistent with measured leak rates for we 11 sealed food pack cans reported in Reference 6 . At this estimated leak rate the fraction of the plutonium metal button that would be corroded is on the order of one percent. This amount would hardly be noticeable on the radiographs. Given the history of the metal items that were examined, it appears that the visibie corrosion that is evident on some items such as that shown in Figure 5 was the result of conditions of storage prior to overpacking in two crimp sealed cans. The rate of this corrosion, visible oxide growth in a few years is significantly higher than that which is calculated from weight change data and observed in the radiographs. This strongly suggests that the reaction rate has been significantly slowed to nearly zero due to lack of reaction products. Increase in weight is a very sensitive measure of container seal quality and rate of metal corrosion. It should continue to be a primary control parameter for determining safety of items in storage and establishing the priority for stabilization processing of metal.

Analyzing the apparent weight gain or loss of sixteen buttons on a case by case basis, it was found that ten items had no change or gained weight, and five lost weight. The weight change on one is unknown because the weight data was not recorded on the data sheet. Graph 1 shows the distribution of the observed weight changes. While negative weight changes are not fully understood at this time there are four mechanisms that explain these changes. First, the weight value recorded on many of the labels was recorded to the nearest gram while the new weights were recorded to the nearest tenth of a gram. The rounding of the original values could be the cause for negative values smaller than a half gram. There is certainly the possibility of bias in calibration of balances used to obtain the weights. Third. the loss of a volatile component in the adhesive of the outside labels could also be responsible for slight weight losses. Some of the tamper indicating seals used on these containers weigh three grams. It is not known what fraction of this weight is adhesive but the potential magnitude of the weight loss of volatiles from the adhesive is the same magnitude of the negative weight changes. Finally, the weights were determined with an 
WHC-SD-CP-TRP-067, Rev. 0

METAL MARCH 1996 INSP

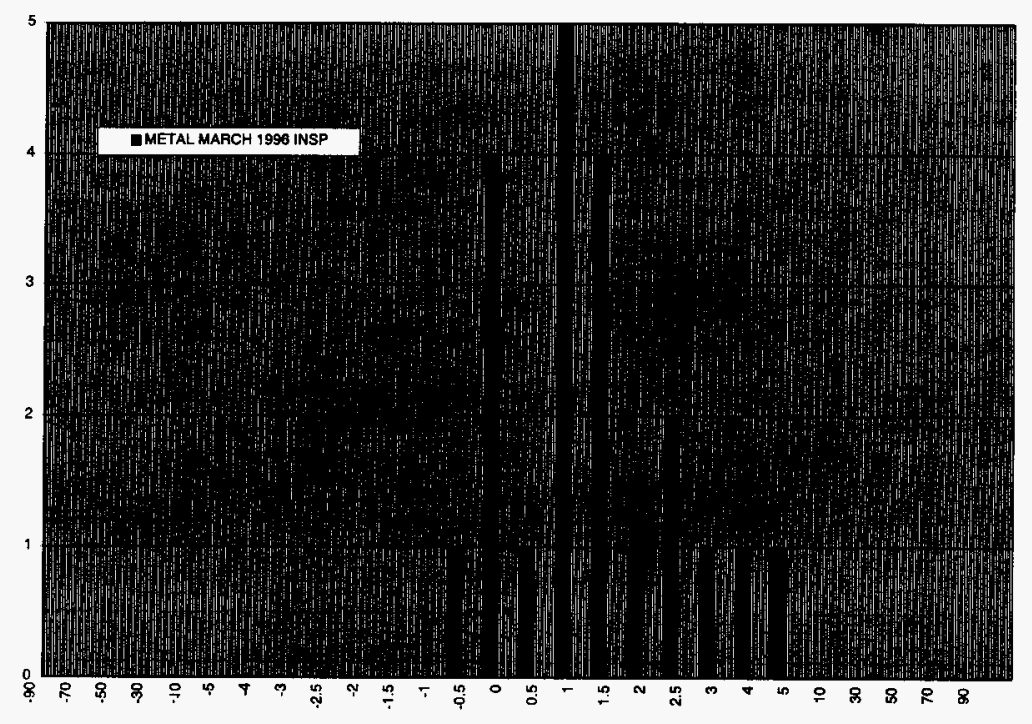

Graph 1 - Distribution of weight changes observed on 15 metal buttons.

electronic label, attached to the can (with varying amounts of adhesives) and a constant weight subtracted from the container weight to estimate the can gross weight. Variability in the weights of the electronic label and amount of adhesive used to attach the electronic label can cause calculated weight losses. 


$$
\text { WHC-SD-CP-TRP-067. Rev. } 0
$$

Assuming that all four of these mechanisms are being exhibited in these data. it is reasonable to assume that the negative changes are indicative of the ability to obtain a true value of weight change. Given these assumptions, one might consider that true weight changes in the contents of the packages can be measured only to about the nearest gram. Even with this Timitation. this figure suggests that there is a possibility that some metal items in the inventory that exceed a five gram weight increase. It is recommended that additional metal items be examined for weight changes in the next phase of this inventory characterization activity to better define the distribution curve. The distribution curve can then be used to estimate the likelihood of having a container in the inventory with an excessive weight gain indicative of a ongoing corrosion of the metal.

\section{Small Metal Pieces}

On the basis of the five small metal pieces observed, it is concluded that there is great variability in condition of metal and packaging methods for this type of item. It is recommended that small metal pieces should be considered as a distinct subset of the metal inventory. It is also recommended that future radiography include small metal pieces to gain a better understanding of this subset of the inventory. From a safety standpoint, these items appear not to pose a significant threat of breach of containers because in all cases the free volume and clearance between the metal and can walls appear to be more than adequate to contain all the powder that could be produced by full conversion of the metal to oxide. Individual items are discussed below.

+ Plutonium Metal Shavings (Item 41-88-09-214)

This item was removed from the $2736-Z$ vaults due to concerns that it may spontaneously oxidize due to the greater than average surface area to mass ratio. It was placed into a vault with specially designed drawers that are ventilated in a way as to prevent contamination should an item ever leak contamination. A test plan is being written to process this item through the Thermal Stabilization Process.

+ Metal Chunk (Item 41-84-11-446)

In 1984, the gross weight of the item was recorded to the nearest gram as 614 grams. In March of 1996, the gross weight was 615.1 grams. a gain of 0.6 to 1.6 grams depending on how much 614 was rounded. Based on weight gain and the X-ray image. the metal does not appear to be significantly oxidized.

+ Recastable Metal (Item 92-79-02-01)

The recastable metal appears to be packaged adequately, however the loose powder observed is not consistent with the lack of weight gain. 
WHC-SD-CP-TRP-067, Rev. 0

Further study of this item is recommended to reconcile the disparity. No action is required pertaining to this item based on lack of weight gain. Similar metal items should be examined using radiography.

+ Partial Buttons

Based on records, it is believed that a button was broken into six different pieces. Five of the pieces were packaged and are currently in the inventory. It is not known what happened to the sixth piece. The two items that were examined, had signs of significant oxidation. Because of concern for the condition of the observed partial buttons. inventory records were examined to see if additional partial buttons beyond the five discussed here exist in the inventory. None were found. These five items have been placed into a vault with specially designed drawers that are ventilated in a way as to prevent contamination should an item ever leak. The five items will be processed through the Thermal Stabilization Process to form high fired plutonium oxide. This will eliminate this subset of the metal inventory.

For the can that was radiographed, the significance of the 2.7 weight gain relative to the 213 grams of metal in the can was evaluated. To estimate a can in-leakage rate it is assumed that the metal reacted with oxygen and/or nitrogen from air leaking into the container. Both plutonium oxide and plutonium nitride have been known to form on plutonium metal in storage. The differences in percentage of these compounds does not significantly affect calculated leak rates. To gain 2.7 grams by reaction with air about 1.9 liters of air would have had to pass from the outside of the foodpack cans to the metal since the time it was packaged (ie. Nov, 1979). This calculates to a leak rate of $1.78 \times 105 \mathrm{cc} / \mathrm{sec}$. The $2.7 \mathrm{gram}$ increase would indicate about twenty grams or almost ten percent of plutonium metal would have reacted with dir. Figure 9 suggests the original oxide is present within the plastic bag inside the inner can. consistent with these calculations. There appears to adequate free volume in the innermost can that complete reaction of the metal with air would not jeopardize the package integrity due to lower density oxide filling the can.

The relative risks of inventory items containing plutonium metal pieces may be established by consideration of several variables. Some of the more important parameters are gain in weight indicative of container leakage. loss of integrity of one or more of the containers. number of sealed containers excluding air from the metal, and the amount of axial and radial space between the metal piece and inner container walls available to accommodate oxide that may form relative to shape and size of the metal piece. Other parameters are age of containers, total decay neat extent of oxide or other compounds already present on the metal. metal1ic phase of the plutonium and history of stability of like items. One can use event tree type evaluations to establish relative risks of 


$$
\text { WHC-SD-CP-TRP-067, Rev. } 0
$$

the metal items using the aforementioned parameters. For $\mathrm{N}$ selected parameters defined such that there are only two choices indicative of relative risks event tree modeling results in $2^{*}$ different combinations of the parameters, each of which has a different relative risk. The sixteen plutonium buttons examined by radiography were evaluated using the four parameters listed above as the more important parameters for illustrative purposes. The criteria used and results are presented in Table 1. In Table 1 the higher relative risk of each criterion moves the item upward on the table resulting in the right hand column being a listing of decreasing relative risks of these sixteen metal buttons. 
Table 1

\begin{tabular}{|c|c|c|c|c|}
\hline $\begin{array}{l}\text { Items } \\
\text { Examined }\end{array}$ & $\begin{array}{l}\text { Weight gain } \\
\text { over } 5 \text { grams? } \\
\text { Yes/No }\end{array}$ & $\begin{array}{l}\text { Visible Loss } \\
\text { of Container } \\
\text { Integrity? } \\
\text { Yes/No }\end{array}$ & $\begin{array}{l}\text { Number of } \\
\text { sealed } \\
\text { containers? } \\
\text { Not more than } \\
2 / \text { More than } 2\end{array}$ & $\begin{array}{l}\text { Room for } \\
\text { oxide } \\
\text { formation? } \\
\text { No/Yes }\end{array}$ \\
\hline \multirow[t]{16}{*}{16} & \multirow[t]{8}{*}{0} & \multirow[t]{4}{*}{0} & \multirow[t]{2}{*}{0} & 0 \\
\hline & & & & 0 \\
\hline & & & \multirow[t]{2}{*}{0} & 0 \\
\hline & & & & 0 \\
\hline & & \multirow[t]{4}{*}{0} & \multirow[t]{2}{*}{0} & 0 \\
\hline & & & & 0 \\
\hline & & & \multirow[t]{2}{*}{0} & 0 \\
\hline & & & & 0 \\
\hline & \multirow[t]{8}{*}{16} & \multirow[t]{4}{*}{0} & \multirow[t]{2}{*}{0} & 0 \\
\hline & & & & 0 \\
\hline & & & \multirow[t]{2}{*}{0} & 0 \\
\hline & & & & 0 \\
\hline & & \multirow[t]{4}{*}{16} & \multirow[t]{2}{*}{4} & 4 \\
\hline & & & & 0 \\
\hline & & & \multirow[t]{2}{*}{12} & 12 \\
\hline & & & & 0 \\
\hline
\end{tabular}

Table 1 is presented to illustrate how relative risks of these superficially similar items can be established. It is recommended that additional metal items be examined and the event tree type evaluation be expanded in the next phase of inventory characterization to include the additional parameters to gain a better understanding of the risks presented by the metal items currently in storage. If a significant fraction of the metal inventory is sampled, the sampling can be used to establish a prediction of the percentage of the inventory that fall into each risk "bin". Metal items should be stabilized in the order of the relative risks established using this methodology. Consideration should be given to applying this technique to other material types using criteria appropriate to the material type. 
WHC-SD-CP-TRP-067, Rev. 0

5. ALLOY

\subsection{Description of Material Tested}

One of 123 alloy items. in the inventory, was examined. Item AL-33-12-10-3 was examined nondestructively using radiography. There are 164 grams of plutonium in this item. The $\mathrm{Pu}^{240}$ is 18.64\%. This material was alloyed with aluminum, consisting of $26.45 \%$ plutonium by weight and what is believed to be $73.55 \%$ aluminum by weight.

\subsection{Test Results}

The radiography images show what appear to be plates. There is no sign of oxidation as can be seem in the well defined edges shown in Figures 10 and 11 . This material gained 3.9 grams going from 959 grams. as indicated on the labe 7 . to 962.9 grams when weighed. This materia? is packaged in two foodpack cans.

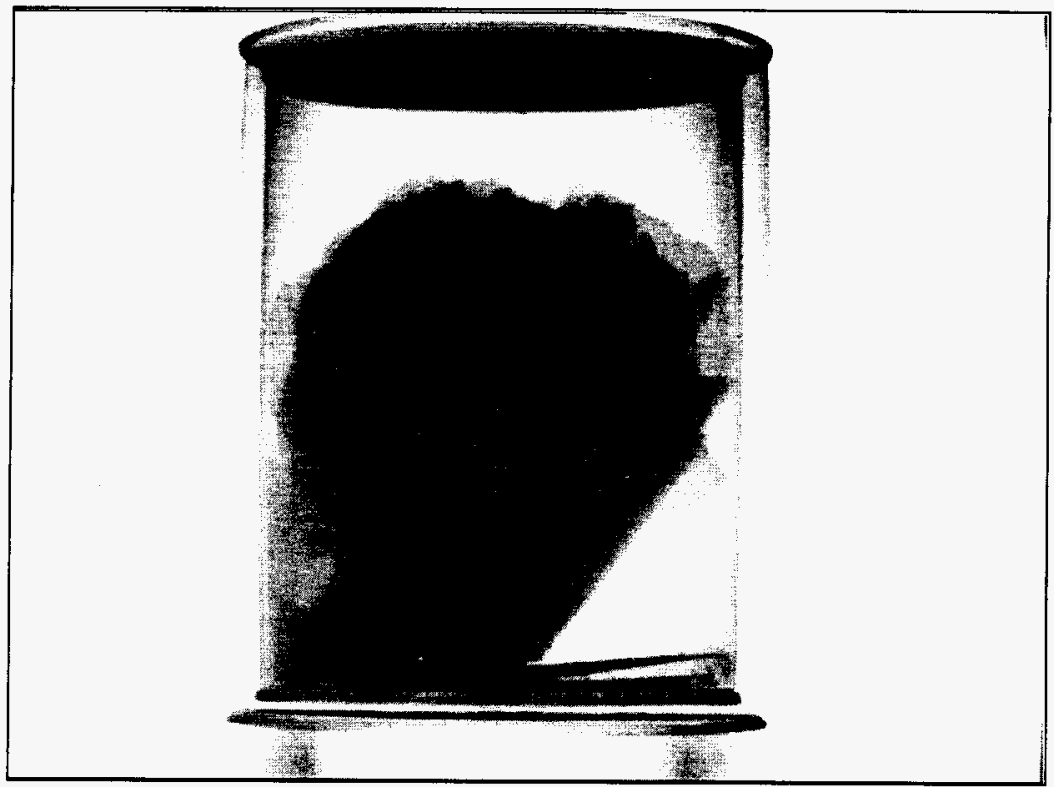

Figure 10 - Alloy item AL-33-12-10-3 appears to be meta17ic plates. 
WHC-SD-CP-TRP-067, Rev. 0

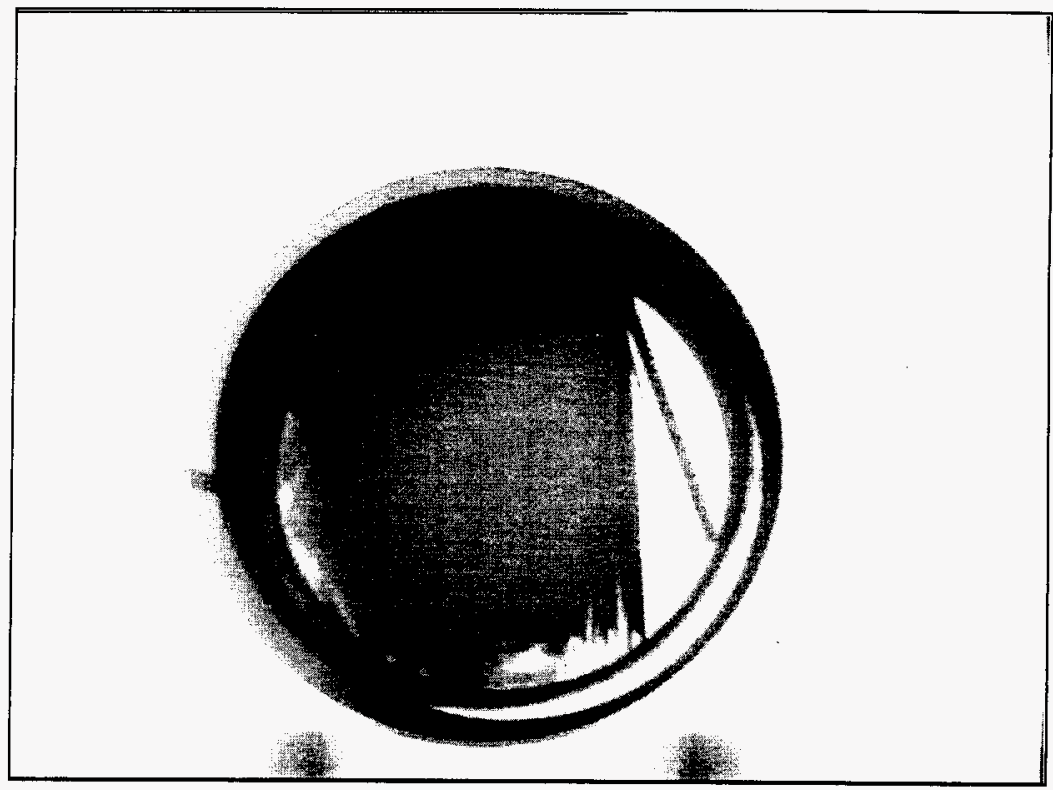

Figure 11 - A view from the top of the can of alloy item AL-33-12-10-3. 


\subsection{Conclusions and Recommendations}

The material within item AL-33-12-10-3 does not appear from the X-ray images to be degrading. This may be due to most of the material being aluminum. The material is packaged in two foodpack cans.

Radiography should be continued to gain additional information regarding the variability and condition of other alloy items in the inventory. 
WHC-SD-CP-TRP-067, Rev. 0

6. OXIDES AND COMPOUNDS (Not Product or Stabilized)

\subsection{Description of Material Tested}

\section{$\underline{\text { Oxides }}$}

Six items. that were not known to be stabilized to a temperature of at least $450^{\circ} \mathrm{C}$, were examined using radiography. These six items are DzO35-09-016. AUA-37-03-011, ZOM-78-06-48, 20726. 20090, and 23821. Each one of these oxides is unique, either in how they were processed or in how they were packaged. Not all of these oxides originated at Hanford.

\section{Laboratory Scrap}

Two miscellaneous laboratory scrap items were chosen due to the high plutonium concentrations in the items. 41-85-08-1381 was chosen due to its plutonium weight ( 120 grams) being equal to its net weight (120 grams). 41-85-03-546 had a plutonium weight of 144 grams. Its net weight was 145 grams.

\section{Plutonium Fluoride Source}

A sealed welded container in container source (102-F-200-6) containing 200 grams of plutonium fluoride, manufactured around 1966. was removed from a five pound slip lid can and placed into a foodpack can so that it could be assayed using non-destructive methods. This transfer was videotaped. A visual inspection was performed along with a contamination survey.

\subsection{Test Results}

\section{$\underline{\text { Oxides }}$}

Six different types of items identified as plutonium oxide were selected and examined. Five of the items appeared to be packaged according to the current vault specifications. One item. (ZOM-78-06-48) was packaged in what appears to be a paint can inside a 7 " can. The X-ray (Fig. 12) suggests the wall thickness of this paint can is thicker than most of the foodpack cans observed. This material can was discolored as though the surface had different wal1 thicknesses throughout the entire can. This may be due to surface rust. This item gained 2.5 grams

Three of the five oxides examined in this group had weight gains greater than two grams. DZO-35-09-016 had the greatest gain at 15 grams. The other item gain was AUA-37-03-011 with 2.2 grams gained. No obvious bulges. deformations, poor can seals or corrosion were observed on the radiograph images for any of the oxide items other than ZOM-78-06-48. 
WHC-SD-CP-TRP-067. Rev. 0

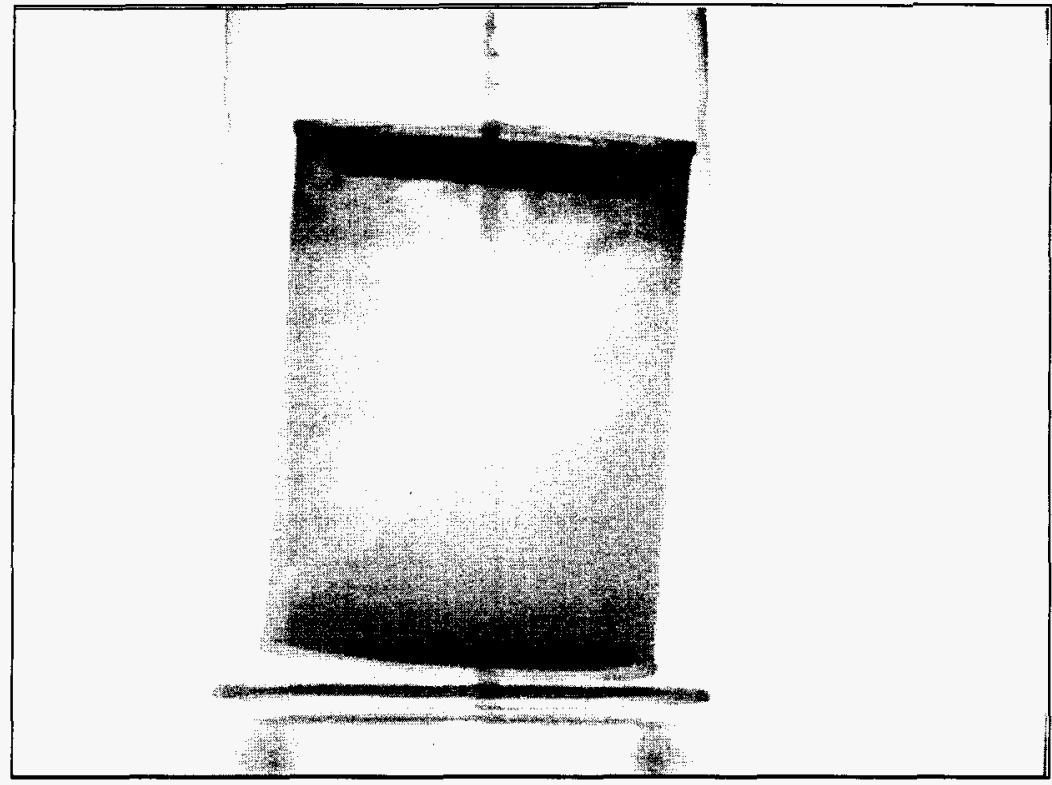

Figure 12 - Item ZQM-78-06-48

Uneven wall thickness of inner container suggests significant container corrosion.

\section{Laboratory Scrap}

Two items of laboratory scrap were selected for examination (41-85-08-1381 and 41-85-03-546). The criteria for examining these items was the plutonium weight matching or almost matching the net weight.

There was great variation between the items. The two different types of scrap items are described individually below. Two other laboratory scrap items were described in the Metals section. 
WHC-SD-CP-TRP-067. Rev. 0

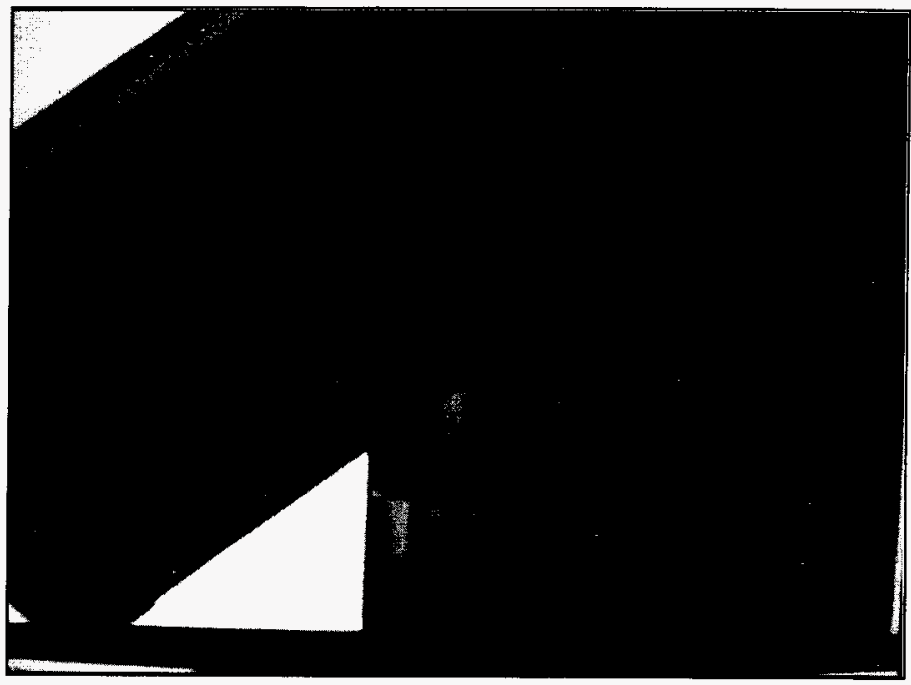

Figure 13

41-85-08-1381 within 50 pound lard can

+ Sample Bottles (41-85-08-1381)

This item consisted of one of two $7^{\prime \prime}$ cans being contained within a lard can. Within the 7" cans were dozens of very small sample bottles. It is not known if the sample bottles contain plutonium metal or oxide. Documentation states that the net weight (120 grams) is identical to the plutonium weight. In theory, this material should be metal. 


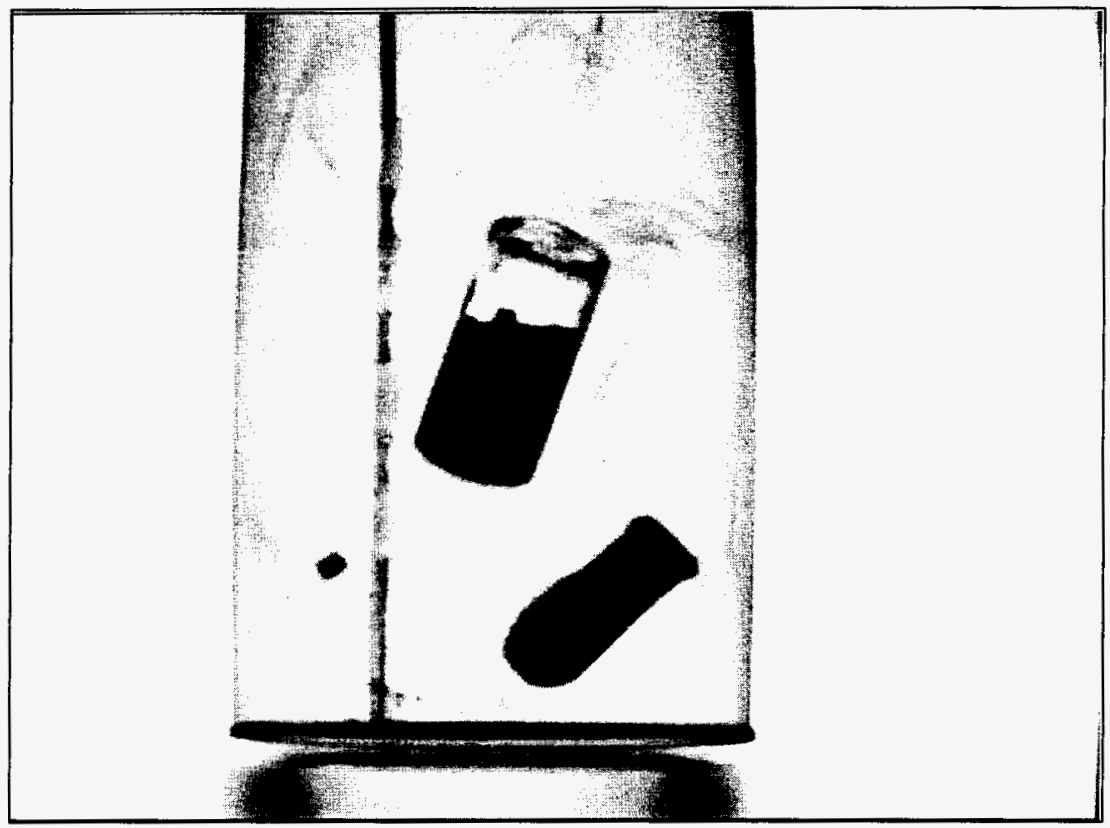

Figure $14-41-85-03-546$

+ Three Sample Bottles (41-85-03-546)

Three containers were sealed out and the bag placed into a 7" foodpack can. This item was chosen to $x$-ray due to information stating that the material is greater than 99\% plutonium. The plutonium weight is 144 grams while the net weight is 145 grams. There was only 0.1 gram of weight gain in this item since it was packaged ten years ago.

The first container. located to the right of center and near the bottom of the can in Figure 14, appears to be a cylindrical container that is packed full of material. The bottom of this container appears deformed as though there is an expansion of the material inside the container. The end that is not deformed has a lip around it. 
WHC-SD-CP-TRP-067. Rev. 0

The second container located highest in the container and in the center of the can, as shown in Figure 14, is cylindrical and filled about two thirds with material. It appears to be made out of glass. There is a sharply defined chunk in the container at the top of what otherwise appears to be powder.

There is also a small chunk of material that is in a third sample bottle that is barely discernable on the radiograph. This container is thought to be plastic. On one image, this chunk is square while other $X$-ray images show it to be cylindrical.

\section{Plutonium Fluoride Source}

The five pound slip lid can was in perfect condition. The thirty year old sealed source (102-F-200-6) which contains the plutonium fluoride was swiped for removable contamination and none was found. Positive response of an alpha survey instrument at the bottom of the container suggests it had fixed contamination on the bottom of it. The welded closure of this source is at the top of the container. An individual. who was involved in use of the sealed container. suggested that it is not fixed contamination but rather instrument probe "noise" caused by high radiation field associated with the source and proximity to the source.

\section{3 Conclusions and Recommendations}

\section{Oxides}

One item out of six of powdered material was packaged in a questionable configuration due to what appears to be only two cans and corrosion of the material can. It is recommended that ZOM-78-06-48 be opened for visual examination. sampled for L.0I, thermally stabilized if necessary, and repackaged to meet vault storage criteria. Additional ZQM items should be examined using radiography.

The reason for the sizable weight gain of item 0Z0-35-09-016 is not fully understood. Further examination of similar items to see if they aiso have gained weight is recommended. This item will be opened to determine if the tomato can is under vacuum.

These six items are too small of a percentage of the total 4768 items in this category to draw conclusions on the category. Additional items should be examined using radiography to gain a better understanding of this material category. 


\section{Laboratory Scrap}

+ Sample Bottles (41-85-08-1381)

These sample bottles will be examined, the contents combined and thermally stabilized. A sample will be taken for LOI and then the material repackaged if it meets vault storage criteria.

+ Three Sample Bottles (41-85-11-446)

The way this item is packaged is questionable. This item will be opened using a work plan. The heterogeneous nature of the contents of this inventory item suggests little knowledge will be gained without extensive sampling and analysis. There is only one foodpack can providing containment, thus the item does not meet current vault storage packaging requirements for two outer foodpack cans. It is recommended that this item be directly processed through the Thermal Stabilization Process, sampled for LOI and then repackaged if it meets the vault storage criteria.

Plutonium Fluoride Source

Visual observation of the outside of the source provided no information on the safety of this item. There is a potential for a high internal pressure to exist. It is recommended that this container be radiographed or otherwise evaluated for excessive internal pressure. 
7. OXIDES THERMALLY STABILIZED UNDER $950^{\circ} \mathrm{C}$

\subsection{Description of Material Tested}

$\underline{\text { Oxides }}$

Six oxide items, BLO-39-11-17-007. ARF-102-85-309-S. LA0-CO9-226. C0-28-01-055. PS-35-12-021, and 61-85-05-651 were examined nondestructively using radiography. Each one of these oxides is unique. either in how they were processed or in how they were packaged. Not all of these oxides originated at Hanford.

Seven plutonium oxide items from the same off site source were opened and sampled in the repackaging glovebox in 2736-ZB. The foodpack cans were visual7y examined as they were opened. A1l steps in the opening of ARF-102-85-304 and selected portions of other containers were videotaped. The items examined were ARF-102-85-435. ARF-102-85-533, ARF-102-85-473. ARF-102-85-567. ARF-102-85-114. ARF-102-85-230 and ARF - 102-85-304.

ARF $-100-86-349$

One item of stabilized ash (ARF-100-86-349), was selected from a PFP vault for destructive examination based only upon the discoloration formed on the exterior of the $7^{\prime \prime}$ can. The discoloration is believed to be a black surface rust forming on the containers due to the moisture in the ventilation inlet air. This item was packaged in 1986. There were several cans with similar discoloration in this vault. Examination was needed to determine whether the discoloration has had any negative effect on the integrity of the outer can. The vault. from which this item was removed, has a history of developing condensation on the walls during winter months. This group of discolored cans is located near the air supply inlet in the vault. The item was deemed to be in the poorest condition, in regard to the amount of discoloration on the $7^{\prime \prime}$ can. The item contained 158 grams of plutonium in the form of stabilized ash.

Stabilized Ash

Seventy stabilized ash items were visually inspected, when opened for reprocessing at $950^{\circ} \mathrm{C}$ in the Thermal Stabilization Process. The list of items is in the appendix found in WHC-SD-CP-TRP-065. 
WHC-SD-CP-TRP-067. Rev. 0

\subsection{Test Results}

\section{Oxides}

Six oxide items. BL-0-39-11-17-007. ARF-102-85-309-S, LAO-CO9-226. C0-28-01-055, PS-35-12-021, and 61-85-05-651 were examined using radiography. These items show no evidence of corrosion. poorly made crimp seals, pressurization, or bulging. BL0-39-11-17-007 did gain 12.3 grams of mass. At this time, there is no explanation to this weight gain. All of the other oxide items in this group had weight gains of less than one gram.

Of the seven ARF oxide items, that were opened and sampled on August 21st and 22nd. 1995, a 11 were packaged and shipped to PFP from another DOE site. Within each of the seven items the plutonium oxide was packaged in a crimp sealed can. This material can in turn was sealed out in PVC. This was then placed into a inner can which appeared to have the dimensions of the PUREX secondary can. This inner can was then placed inside a 7" can.

A11 seven items were in good condition on the exterior of the $7^{\prime \prime}$ can. There was no rust or signs of bulging. The interior of the $7^{\text {" cans were }}$ shiny and free of any rust. The seven inner cans were also in good condition inside and out. Three of the items had some residue from the PVC seal-out bag on the interior of the inner can. The PVC was clear on one item and discolored on six of the other seal out bags. Three seal out bags had a brownish tinge. The other three sea? out bags were highly discolored and were the items that had the PVC residue on the interior of the inner cans. The PVC residue was also on the material cans.

Of the three cans with highly discolored bags, one can had marks left on it resulting from contact with the PVC. There were corresponding marks on the PVC seal out bag. The marks were whitish while the surrounding discolored PVC was a reddish purple. The top of this PVC seal-out bag. which was not near the plutonium oxide. was. still clear. Apparently the closer the PVC was to the material, the more degraded it became suggesting heat related degradation. The PVC tore easily in the discolored portion when ripped by an operator. When the rip reached the milky white (non-degraded) portion of the PVC it ceased to rip. The discolored or degraded PVC. while easily torn. was not brittle. The other two PVC seal out bags did not leave markings on the material can. but like the interior on the inner can. left a whitish residual.

The plutonium oxide was a fine brown powder. A couple of items had some hard clumps of material. One of these items also had some white specks in it. It is speculated that this may have been talcum powder. The material cans were in good condition both externally and internal7y. ARF-102-86-304 was videotaped as it was being opened. Specific data on the other six items is in the appendix. 
WHC-SD-CP-TRP-067, Rev. O

ARF $-100-86-349$

The item was sealed into the repackaging glovebox and the $7 "$ can opened.

The interior of the 7" can was shiny with no signs of deterioration.

The exterior of the inner can was shiny and looked new. There was no sign of bulging. This item was not examined any further.

Stabilized Ash

Seventy items were opened to be processed through the Thermal Stabilization Process. Twenty five of these items had detailed information regarding the packaging condition gathered on them. Data was gathered primarily by Thermal Stabilization Operations through visual inspection of the containers. It is reported that. of the twenty five, there was only one slip lid can that had pressurized. The only other concern with the integrity of the containers was that the PVC seal-out bags were discolored, indicating degrading of the seal-out bags.

\subsection{Conclusions and Recommendations}

Continue radiography of other oxide items to gain additional information. Various items will be identified to be opened and sampled for LOI.

Oxides

Six oxide items. BL0-39-11-17-007 and ARF-102-85-309-S. LAO-CO9-226. C0-28-01-055. PS-35-12-021, and 61-85-05-651 were examined using radiography. BL0-39-11-17-007 had a weight gain of 12.3 grams. There is no explanation for this gain at this time. Other BLO items will be examined using radiography. These items appeared to be packaged well.

The seven oxide items that were opened to be sampled were in good condition. The only degradation was the PVC seal out bag around the material can. This barrier is not taken into account for the double containment.

ARF-100-86-349

The interior of the exterior can showed no signs of discoloration. This was also true of the exterior of the inner can. Since one of the oldest and most discolored cans was chosen from the vault for examination, it is concluded that there is no immediate threat to the integrity of the less discolored cans due to corrosion. It is recommended that the existing monthly visual inspection of these containers be continued to assure that the rate of discoloration/rusting is not changing. 
WHC-SD-CP-TRP-067. Rev. 0

Stabilized Ash

Seventy stabilized ash items were opened and processed to over $950^{\circ} \mathrm{C}$ in the Thermal Stabilization Process. No further action is needed on the stabilized ash that not been processed through the Thermal Stabilization Process. This stabilized ash appears to be packaged adequately and the estimated container life is acceptable for the near term, until packaging or stabilization is defined.

8. OXIDES THERMALLY STABILIZED OVER $950^{\circ} \mathrm{C}$

8.1 Description of Material Tested

Thermally Stabilized Material

One item. (64-95-05-129), stabilized in the Thermal Stabilization Process and packaged in 1995, was examined nondestructively using radiography.

\subsection{Test Results}

Thermallv Stabilized Material

This item was recently processed through the Thermal Stabilization Process as glovebox sludge. The material is contained in a PUREX slip lid can. It was then sealed out using PVC and canned into a PUREX secondary can and overpacked in a 7" can. There were no bulges or weight changes.

\subsection{Conclusions and Recommendations}

Thermally Stabilized Material

At this time, no action is warranted for 64-95-05-129 since there is no apparent loss of integrity in the packaging of this material. This item was one of several new items packaged in 1995 from processing sludge. unstabilized ash and stabilized ash. 
WHC-SD-CP-TRP-067. Rev. 0

\section{CONCLUSIONS AND RECOMMENDATIONS}

Based on the analysis of the 169 items considered in this evaluation several conclusions can be drawn and recommendations can be made. These conclusions are drawn from limited amounts of data and are not based on a statistically significant number of observations in most instances. General conclusions on the inventory as a whole and specific subsets follow.

General Conclusions:

1. The risk model established in Reference 1 and presented as Table 2 appears to adequately establish priorities for stabilization of materials.

2. The items observed, in general, represent those items in the inventory that were judged to be the highest risk. Containers were selected because of extremes of age, heat content, mass of plutonium and degree of kriowledge of contents. The observations were made on about $2 \%$ of the inventory. There were no observations of past or imminent container integrity failures that would result in release of contamination to the storage facility or workers. Based on these facts it is concluded that the failure rate of the containers in the existing inventory is extremely low. consistent with the nearly perfect record of contamination control in the $2736-Z$ storage vault since its initial loading in 1970.

3. The observed weight gains of plutonium metal items is very low and indicative of very low air in-leakage rates (on the order of $10^{-5}$ $\mathrm{cc} / \mathrm{sec})$. There is no indication of catastrophic failure of container seals, however, the fraction of the inventory sampled was smal?. Weight gains due to corrosion of plutonium at observed rates is not of concern for the next decade assuming no catastrophic failures of container integrity. Although they also had very low calculated container leakage rates. oxides and oxide like materials had noticeably greater weight gains than metal containers.

4. Not all packages were packaged as currently specified by PFP operating specifications for vault storage. Some of these containers were packaged subsequent to the date that the requirements were established. None, however, represented an imminent threat to container integrity.

5. Several of the facility defined inventory material categories, such as Laboratory Scrap, are highly variable in physical nature of the material and packaging. Small samples of such categories can only be considered indicators of conditions. 
WHC-SD-CP-TRP-067. Rev. 0

The following recommendations are made based on the specific conclusions drawn for each material category presented in this document and the general conclusions stated above.

\section{Recommendations:}

1. Because of the multiple containers of slag and crucible fragments within a 50 pound lard can make examination by radiography difficult. these containers should be evaluated by physical observations.

2 Increase in weight of plutonium metal containers should continue to be the primary control parameter for determining safety of items in storage. Additional metal items should be examined by radiography and weighing to gain a better estimate of weight gain distribution over the entire metal inventory. Based on results from a larger sample size. weighing each metal item in the inventory at an established frequency may be indicated.

3. Because of the variability of physical appearance and packaging of sma 11 pieces of metal and laboratory scrap in the inventory it is recommended that al1 these items be evaluated by review of records or examination by radiography to assess their relative priority for stabilization.

4. Those items not packaged in accordance with current vault criteria or suspect items, such as ZQM-78-06-48, should be considered as higher relative risk items and repackaged. following stabilization if appropriate. Seven (7) of forty two (42) such items have been identified

5 Radiograph additiona i items from sparsely populated categories, such as alloys, to gain a better understanding of the characteristics of such categories.

6. Examine additional oxide containers by radiography and obtain weight data to gain a better understanding of performance of oxide containers while in storage.

The plans for an iterative approach to radiography and physical examination of containers followed by technical evaluation of data documented in Reference 1 provide the mechanisms to implement these recommendations. 
WHC-SD-CP-TRP-067. Rev. 0

10. REFERENCES

1. Letter from E. C. Vogt to O. A. Farabee, "Plutonium Vulnerability Management Plan". March 31. 1995, Letter No. 9551735

2. WHC-SD-CP-TP-086, Rev. 1. "Plan to Examine Special Nuclear Material and the Foodpack Containers at the Plutonium Finishing Plant Storage Vaults". G. R. Wittman, October 24, 1995

3. Work Plan PFP-96-V0-009. "Inspection of Special Nuclear Material Using X-ray". G. R. Wittman. March 4. 1996

4. DOE-STD-3013-94, "Criteria for Safe Storage of Plutonium Metals and Oxide", December, 1994

5. Internal Letter from PFP Process Engineering to E. W. Curfman. "Loss on Ignition Analysis for Stabilized Ash Product Cans". IL $15530-95-M L W-088$

6. PNL-5591. "Gas Leak Characteristics of Inner Packaging Components Used in the DOT-Spec 6M Container", J. M. Taylor, September, 1985

7. RHO-HS-SA-59 P. "The Effectiveness of Corrective Actions Taken to Preclude Events Involving Tin Cans and Plutonium". R. W. Szempruch, May, 1984

8. SD-RE-TI-106, "ColTapsed Plutonium Metal Storage Containers". J. F. Washburn. August 12, 1983

9. NMS-EFL-95-0104, "Update on Inwardly Deformed Vault Cans". J. B. Schaade, October 13. 1995

10. ARH-2206. "Plutonium Metal Canning Evaluation". P. E. Wegner. August 20, 1971

11. OSD-2-184-00013, Rev. I-2. "Special Nuclear Material Storage". M. W. Gibson. September 15. 1995

12. Defense Nuclear Facilities Safety Board Recommendation 94-1 Implementation Plan. February 28. 1995

13. WHC-SD-CP-TRP-065. "Appendix 2 of WHC-SD-CP-TRP-067", G. R. Wittman. Ju7y, 1996 
Table 2

Implementation Plan Matrix - March, 1995 Status

\begin{tabular}{|c|c|c|c|c|c|c|c|}
\hline & Liquids & Wet Solids & $\begin{array}{l}\text { Corrosive or } \\
\text { Reactive "dry" } \\
\text { Solids }\end{array}$ & $\begin{array}{l}\text { Metal } \\
\text { and } \\
\text { Alloys }\end{array}$ & $\begin{array}{l}\text { Oxides and } \\
\text { Compounds } \\
\text { (not product } \\
\text { or } \\
\text { st.abi } 1 \text { ized) }\end{array}$ & $\begin{array}{l}\text { Oxides } \\
\text { Stabilized } \\
4950^{\circ} \mathrm{C}\end{array}$ & $\begin{array}{l}\text { Oxides } \\
\text { Stabinazec } \\
>950^{\circ} \mathrm{C}\end{array}$ \\
\hline $\begin{array}{l}\text { Total Items in } \\
\text { Inventory } \\
\text { Relative } \\
\text { Container Life } \\
\text { Expectancy }\end{array}$ & 454 & $\begin{array}{l}-250 \text { in } \\
\text { gloveboxes }\end{array}$ & 838 & 475 & 4769 & 1566 & $\begin{array}{l}-50 \text { from current } \\
\text { stabilization } \\
\text { campaign } \\
\text { (cuantity } \\
\text { changes daily) }\end{array}$ \\
\hline $\begin{array}{l}\text { Remaining } \\
\text { Container Life } \\
\text { Expectancy: } \\
\text { LOWEST } \\
\end{array}$ & $\begin{array}{l}27 \text { high } \mathrm{Cl}^{\circ} \text { in } \\
\text { polybottles }\end{array}$ & $\begin{array}{l}-250 \text { in } \\
\text { gloveboxes }\end{array}$ & 226 polycubes & none & none & none & none \\
\hline $\begin{array}{l}\text { Remaining } \\
\text { Container Life } \\
\text { Expectancy } \\
\text { LOW' MED. }\end{array}$ & $\begin{array}{l}93 \text { other } \\
\text { polybottles } \\
\text { (includes } 30 \\
\text { potentidily } \\
\text { unvented } \\
\text { containers) }\end{array}$ & none & $\begin{array}{l}47 \\
\text { unstabil:zed } \\
\text { ash } \\
17851 \text { ag \& } \\
\text { Crucible } \\
387 \text { other }\end{array}$ & $\begin{array}{l}352 \\
\text { netal }\end{array}$ & none & none & none \\
\hline $\begin{array}{l}\text { Remaining } \\
\text { Container Life } \\
\text { Expectancy } \\
\text { MED. - HIGH }\end{array}$ & 334 PR cans & none & none & $\begin{array}{l}123 \\
\text { a1 loys }\end{array}$ & $\begin{array}{l}4769 \text { Pu and } \\
\text { mixed oxide } \\
\text { (MOX) scrap } \\
\text { powiders } \\
\text { pellets } \\
\text { stabilized } \\
\text { ash etc }\end{array}$ & $\begin{array}{l}1077 \text { Product } \\
\text { Oxide } \\
385 \\
\text { stabi } 1 \text { ized } \\
\text { ash }\end{array}$ & $\begin{array}{l}-50 \text { recent } 7 y \\
\text { stabilized }\end{array}$ \\
\hline $\begin{array}{l}\text { Remaining } \\
\text { Containe Life } \\
\text { Expectancy: } \\
\text { HIGHEST }\end{array}$ & none & none & none & none & none & $\begin{array}{l}104 \text { MOX Pins } \\
\text { and } \\
\text { Asssemblies }\end{array}$ & none \\
\hline
\end{tabular}

Laid out in this fashion. relative risk decreases from left to right and from top to bottom. The highest risk items, and thus highest in priority for stabilization. are in the upper left region of the matrix and the lowest risk items are in the lower right region. The objectives of the stabijization efforts responsive to the DNFSB Recommendation 94-1 will have been met when the entire inventory has been transitioned to the lower right corner of the matrix. Prioritization of materials according to the matrix minimizes residual risk of failures of existing containers while in storage until stabilization and repackaging is achieved. One objective of inventory characterization efforts is to assure that the risk estimate presented by the matrix is valid by assessing container integrity.

Tables 2 and 3 are representations of a hypothetical risk model based on life expectancies of SNM material containers. Data is currently being gathered to verify if the estimates on the expected container life are correct. In the context of plutonium storage at the PFP. there are four levels of concern 
relative to remaining container service life. These may be defined as follows:

Remaining Container Life Expectancy - Lowest is also defined as None: The container is identified as leaking. considered pressurized to the point that repackaging is required as defined in FFP Operating Specification Document OSD-Z-184-00013, or has been evaluated as less than adequate for the material currentiy being stored. These packages could also be described as "Unstable" inventory items.

Remaining Container Life Expectancy - Low-Medium is also defined as Less than 10 years: Because of observed or calculated rates of pressurization or corrosion. the container is expected to have a remaining service life of "None," as described above. within 10 years. These packages could also be described as "Potentialiy Unstable" inventory items.

Remaining Container Life Expectancy - Medium-High is also defined as Between 10 and 50 years: The container is not expected to have a remaining service life of "None." as defined above. for at least 10 years. The expectation is based on observed or calculated rates of pressurization or corrosion. The items could also be described a "Stable for Interim Storage." Only packages containing appropriately characterized materials that have documented evaluations are to be considered in the last category defined in the following paragraph.

Remaining Container Life Expectancy - High is also defined as Greater than 50 years: Packages (e.g. containers loaded with specific characterized materials) that have documented engineering evaluations of expected container longevity in excess of 50 years fal 1 into this category. Packages meeting DOE-STD-3013-94 and unirradiated reactor fuel components (clad rods. pins and fuel assemblies) are expected to fal? into this category. These Items may also be described as "Stable for Long Term Storage. 
Zuodad SL47 uL passnostp

sıaulequoj to suded6olped pue eqep pazelnqez sqzaus eqep quenalad

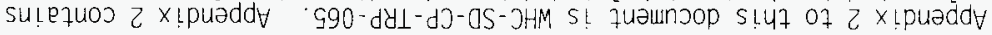

Z XIONJdd $\forall$

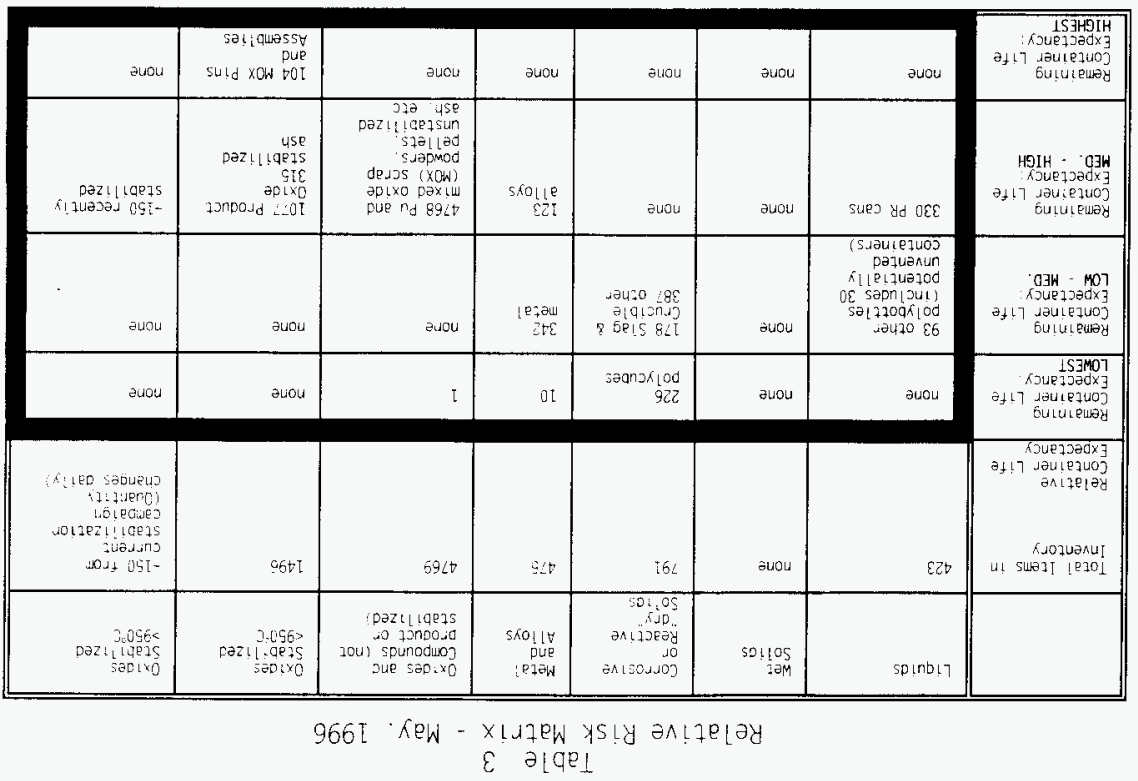

$0 \cdot$ 八əy $\angle 90-d y \perp-d \partial-0 S-J H M$ 


\section{DISTRIBUTION SHEET}

\begin{tabular}{|c|c|c|c|c|c|c|c|c|}
\hline \multirow{2}{*}{\multicolumn{2}{|c|}{$\begin{array}{l}\text { To } \\
\text { Distribution }\end{array}$}} & \multirow{2}{*}{\multicolumn{4}{|c|}{$\begin{array}{l}\text { From } \\
\text { G. R. Wittman }\end{array}$}} & \multicolumn{3}{|c|}{ Page 1 of 1} \\
\hline & & & & & & \multicolumn{3}{|c|}{ Date $7 / 1 / 96$} \\
\hline \multicolumn{6}{|c|}{ Project Title/Work Order } & \multicolumn{3}{|c|}{ EDT No. 609908} \\
\hline \multicolumn{2}{|c|}{ Plutonium Inventory $\mathrm{Cr}$} & tion & chnical & Evaluatic & Report & \multicolumn{3}{|c|}{ ECN No. N/A } \\
\hline & Name & & MSIN & $\begin{array}{c}\text { Text } \\
\text { With All } \\
\text { Attach. }\end{array}$ & Text Onl & & $\begin{array}{l}\text { Attach./ } \\
\text { Appendix } \\
\text { Only }\end{array}$ & $\begin{array}{c}\text { EDT/ECN } \\
\text { Only }\end{array}$ \\
\hline
\end{tabular}

E. P. Bonadie

G. J. Cox

E. W. Curfman

* M. W. Gibson (6)

D. R. Groth

J. M. Held

K. R. Herzog

J. M. Hieb

R. C. Hoyt

T. E. Huber

C. M. Kronvall

D. J. McBride

J. L. Mejia

L. L. Morrison

R. D. Redekopp

L. H. Rodgers

R. W. Szempruch

M. D. Talbot

D. W. Templeton

T. J. Venetz

E. C. Vogt

G. A. Westsik

R. G. Wilbanks

G. R. Wittman
T5-55

T5-50

T5- 05

T5-55

T4-15

T5-11

T5-50

T5- 05

H5- 49

T5-50

T5- 15

T5-54

T5- 08

T5-05

T5-15

T5-53

T5-48

T5- 15

R3-79

H5-49

T5-50

T5-53

T5-08

T5-55 $x$

$x$

$x$

$x$

$x$

$x$

$x$

$x$

$x$

$x$

$x$

$x$

$x$

$X$

$X$

X

$x$

$x$

$x$

$x$

$x$

$x$

$x$
$x$
$x$

\section{* Call}

